\title{
Exploring the evolving motives underlying corporate social responsibility (CSR) disclosures in developing countries: the case of "political CSR" reporting
}

\author{
M. Karim Sorour and Philip J. Shrives \\ Newcastle Business School, Northumbria University, Newcastle upon Tyne, UK \\ Ahmed Ayman El-Sakhawy \\ Arab Academy for Science Technology and Maritime Transport, \\ Alexandria, Egypt, and \\ Teerooven Soobaroyen \\ Essex Business School, University of Essex, Colchester, UK
}

\begin{abstract}
Purpose - This paper seeks to investigate to what extent (and why) CSR reporting in developing countries reflect instrumental and/or "political CSR" motivations and the types of organisational legitimacy sought in these circumstances.

Design/methodology/approach - We adopt a theoretical framework based on neo-institutional theory, "political CSR" framework and types of organisational legitimacy. This interpretive research is set in the Egyptian context post-2011 revolution. We first carry out a content analysis of web disclosures for 40 banks in 2013 and 2016 to ascertain the nature of CSR activities and any changes over time. Second, we draw on 21 interviews to tease out the implications of the change in societal expectations due to the revolution and to deepen our understanding of the organisational motivations underlying CSR reporting.

Findings - Following the 2011 revolution, the banks' CSR reporting practices have gradually shifted from a largely instrumental "business-case" perspective towards a more substantive recognition of a wider set of societal challenges consistent with a political CSR perspective. Overall, the maintaining/gaining of legitimacy is gradually bound to the communication of accounts about the multi-faceted socially valued consequences or structures performed by banks. Our interview data shows that participants reflected on the legitimation challenges brought by the revolution and the limits of transactional strategies involving traditional constituents, with a preference for pursuing consequential and structural forms of moral legitimacy.

Research limitations/implications - This study demonstrates a constructive shift by businesses towards engaging with the new social rules in response to sociopolitical changes and the need to achieve moral legitimacy. Hence, policymakers and stakeholders could consider engaging with different economic sectors to foster more transparent, accountable, and impactful CSR practices.

Originality/value - We highlight the implications of Scherer and Palazzo's political CSR approach for accountability and CSR reporting. CSR reporting in some developing countries has typically been seen as peripheral or a symbolic exercise primarily concerned with placating stakeholders and/or promoting
\end{abstract}

(C) M. Karim Sorour, Philip J. Shrives, Ahmed Ayman El-Sakhawy and Teerooven Soobaroyen. Published by Emerald Publishing Limited. This article is published under the Creative Commons Attribution (CCBY 4.0) licence. Anyone may reproduce, distribute, translate and create derivative works of this article (for both commercial and non-commercial purposes), subject to full attribution to the original publication and authors. The full terms of this licence may be seen at http://creativecommons. org/licences/by/4.0/legalcode

The authors are grateful for the guest editors and the anonymous reviewers of this paper for their valuable comments and suggestions as well as the participants at the 19th Workshop on Accounting and Finance in Emerging Economies- AFEE-BAFA (2019)- for feedback received on an earlier version.

disclosures in developing countries 
AAAJ 34,5

shareholders' interests. We suggest that researchers need to be instead attuned to the possibility of a blend of instrumental and normative motivations.

Keywords Legitimacy, Banks, Developing nations, CSR, Disclosures

Paper type Research paper

\section{Introduction}

Over the last decade or so, there has been sustained research interest in corporate social responsibility (CSR) practices in developing countries (Athanasopoulou and Selsky, 2015; Jamali et al., 2015, 2017; Aguinis and Glavas, 2012; Adelopo et al., 2015). Early work in these contexts has typically highlighted the limited existence of "formalised" CSR initiatives, with CSR mainly motivated by (individual) philanthropic reasons (Jamali and Karam, 2016). However, there has since been a significant uptick in levels of CSR engagement - operationally and strategically that appears to be underpinned by a more complex, varied and nuanced set of motivations (Amaeshi et al., 2016; Jamali and Karam, 2016; Jamali et al., 2017). In parallel, a stream of studies has focused on the reporting of CSR in developing countries (e.g. Amran and Haniffa, 2011; Belal et al., 2013; Soobaroyen and Ntim, 2013; Soobaroyen and Mahadeo, 2016; Ali et al., 2017; Uddin et al., 2018; Li and Belal, 2018) since such forms of communication can potentially provide useful insights on a company's values, strategies, commitment to, and impact on, various societal challenges, e.g. environment, climate change, sustainable development, poverty alleviation and community support (Gallhofer et al., 2011; Global Reporting Initiative, 2017).

Although one can observe a gradual institutionalisation of the practice across many developing countries (Hopper et al., 2017; Uddin et al., 2018; Khan et al., 2020), a key finding has been the largely voluntary and eclectic nature (in form and content) of CSR reporting. These insights have been analysed from a number of theoretical standpoints privileging motives such as reputation/brand building, legitimacy pursuing, resource-seeking, stakeholder managing, agenda-setting or a combination thereof (Ali et al., 2017; Momin and Parker, 2013; Soobaroyen and Mahadeo, 2016; Lauwo et al., 2019; Khan et al., 2020). We contend that these interpretive and critical perspectives are underpinned by a key premise, namely that the over-riding strategic outcome of CSR engagement and reporting is the pursuit of (typically) short-term economic gains. This premise can be evidenced from the researchers' reliance on notions of instrumentality or other "hard-nosed" "business case" logics to frame CSR activities (Brammer et al., 2012; Adelopo et al., 2015) and CSR reporting practices (Bayoud et al., 2012; Amran and Haniffa, 2011; Lehman and Kuruppu, 2017). In this respect, CSR reporting is largely seen as an elaborate form of "greenwashing" (e.g. Marquis et al., 2016), and is often conceptualised as a symbolic management exercise to maintain/gain organisational legitimacy (Ashforth and Gibbs, 1990; Soobaroyen and Ntim, 2013; Cho et al., 2015; Khan et al., 2020).

Although we do not dispute the relevance of this characterisation of CSR reporting, we contend that this may not be (contemporarily) the complete story. There are indications of an evolution towards more normative forms of CSR engagement and reporting, which is underpinned by a deeper acknowledgement of the interdependence between societal concerns and business purpose(s), amidst shifts in institutional-level expectations about the purpose and legitimacy of businesses in society (Scherer and Palazzo, 2011; Scherer et al., 2016). This realisation, albeit partial or gradual, has been noted in a few developing countries (Sannassee et al., 2017; Soobaroyen and Ntim, 2013; Amaeshi et al., 2016; Sorour et al., 2020) in the face of pressing social needs (e.g. health crisis, rural areas with limited infrastructure, economic/social inequalities), emergencies (e.g. conflict, unrest, pandemics, natural disasters) and "disruptions" to long-standing political-economy structures (e.g. rise of populist governments, lingering economic contractions, changing geopolitical orders, the backlash against Western models of neoliberal governance and social welfare/justice). In such cases, we argue that organisational legitimacy and legitimation may be predicated on the need for companies to deliver the core, rather than peripheral, social engagement and responsibility activities in developing 
countries (Ashforth and Gibbs, 1990; Suchman, 1995). Hence, subtler CSR "reporting logics" might be at play in developing countries (as hinted by Jamali et al., 2017).

It is in this light that we draw upon the notion of "Political CSR" (Scherer et al., 2016; Scherer and Palazzo, 2011), which conceives firms as political, and not merely economic, actors. Specifically, political CSR “... entails those responsible business activities that turn corporations into political actors, by engaging in public deliberations, collective decisions, and the provision of public goods or the restriction of public bads in cases where public authorities are unable or unwilling to fulfil this role" (Scherer et al., 2016, p. 276). Consequently, CSR practices, structures and accountability are (or become) less underpinned by an instrumental "business case" mindset and instead, these are (or become) more driven by a normative and moral dimension towards "...enhancing social welfare" (Scherer, 2018, p. 394). Furthermore, an important consideration of the political CSR approach is the recognition of weak or absent state institutions - akin to Amaeshi et al.'s (2016) concept of "institutional void"- and the implication that a firm's CSR activities and reporting may, for example, encompass the delivery of public goods or services, such as health, education and infrastructure. While prior CSR reporting studies have highlighted instances of "deeper" forms of corporate involvement (refer to Ali et al., 2017; Khan et al., 2020), they do not provide a comprehensive understanding of instrumental vs. political forms of CSR reporting (and/or shifts thereof) and the different types of organisational legitimacy (pragmatic vs. moral) being pursued or addressed in those circumstances (Suchman, 1995). Therefore, we raise the following questions: To what extent (and why) does CSR reporting in developing countries reflect instrumental and/or political CSR motivations? What are the types of organisational legitimacy being emphasised by these CSR reporting practices?

To address these research questions, we focus on the case of Egypt's post-2011 revolution, and specifically, the case of its banking sector. Similar to the case of many developing countries (e.g. Tanzania, Nigeria, Bangladesh), businesses in Egypt have had a chequered history in terms of their contribution to society coupled with a tendency to privilege affiliations with powerful state actors (Lauwo et al., 2019; Egbon et al., 2018; Uddin et al., 2018). At best, Egyptian businesses conflated CSR with philanthropy, and at worst, they were seen to be rent-seeking and "socially irresponsible" (Alshorbagy, 2016, p. 11). Although the 2011 revolution (Teti and Gervasio, 2011) arose from long-standing demands for political liberalism and democratic forms of governance, the corporate sector was also heavily criticised due to its involvement in public corruption (Fadel, 2011), crony capitalism and questionable bank lending practices (Chekir and Diwan, 2014; Abdou and Zaazou, 2013). Thus, at one level, it was expected that the new government would bring about reforms to enhance companies' (including the banking sector, in light of its economic prominence [1] involvement in addressing these societal concerns (Alshorbagy, 2016). With respect to the banking sector, the Central Bank of Egypt's (CBE) issued a new corporate governance directive requiring banks to report their social responsibility plans and actions (CBE, 2011). Furthermore, a "heightened" political and social environment developed in terms of involving all Egyptians in resolving long-standing challenges such as inequality/poverty and poor public services (Avina, 2013). This reflected a material change in the "socially constructed system of norms, values, beliefs and definitions" (Suchman, 1995, p. 574), which underpin whether the actions of an entity (i.e. Egyptian banks) are perceived or assumed to be desirable, proper or appropriate. Together with Scherer and Palazzo's (2011) instrumental vs. political CSR approach and Scott's (2014) neo-institutional perspective, Suchman's (1995) thoughts provide the theoretical frame for our research questions. Methodologically, our paper relies on a two-stage approach. First, we review and analyse the online CSR disclosures in 2013 and 2016 for all CBE-registered banks in accordance with the instrumental and political CSR perspectives. Second, we draw on 21 semi-structured interviews with banks' senior executives and CSR managers, CSR academics/consultants and government officials to complement the analysis by considering the types of legitimacy being sought, namely pragmatic legitimacy (exchange) and moral legitimacy (consequential and structural).

\section{disclosures in developing countries}

1053 
AAAJ 34,5

1054

The findings reveal that, in Egypt's post-2011 revolutionary period, the banks' CSR reporting has gradually shifted from a largely instrumental "business-case" perspective (i.e. employees, customers, regulator/rules) towards a more substantive recognition of a wider set of societal challenges and stakeholders (including the environment, human rights, and supporting public services) that is consistent with a political CSR perspective, aligned to the pursuit of moral legitimacy and the State's new developmental agenda. Such normative forces foster the emergence of a CSR norm for businesses to act beyond economic rationality, particularly in the case of state-owned banks relative to foreign and local private banks. Overall, the maintaining (and/or gaining) of organisational legitimacy appears to be gradually bound to the communication of accounts on the multi-faceted socially valued consequences or structures performed by banks (e.g. investing in education/health/poverty projects, adopting environmental and sustainability policies, setting up charitable foundations). Our interview data reveal that participants have deeply reflected on the legitimation challenges brought by the 2011 revolution and have appreciated the limits of transactional strategies involving traditional constituents, with a preference for pursuing consequential and structural forms of moral legitimacy. Our contribution first lies in uncovering evidence of CSR reporting amidst a significant political change in Egypt and the deeper motivations underlying CSR engagement as opposed to previously reported instances of transactional motives (Darrag and Crowther, 2017), image enhancement (Osman, 2019) and instrumental stakeholder management (El-Bassiouny and Letmathe, 2019). Second, and conceptually, we bring to the fore the implications of instrumental and political CSR (Scherer et al., 2016; Scherer, 2018) to the accounting literature and to the context of developing countries. For instance, and drawing upon Ashforth and Gibbs (1990), Kim et al. (2007), Hrasky (2012), Soobaroyen and Ntim (2013), Chelli et al. (2019) and Vithana et al. (2019) articulated how (and why) CSR disclosures may reflect substantive features rather than symbolic ones as a means to align with specific pragmatic and/or moral forms of legitimacy. Distinctively, we emphasise how (and why) an organisational preference for a particular CSR reporting theme (and its related "audiences") reflects the embedding (albeit partially) of a normative "political CSR" thinking aimed at enhancing moral legitimacy in the face of a changing political landscape associated with the role of the business sector in national development initiatives. Furthermore, the interview data highlights an evolution in organisational motives about CSR reporting that is less concerned with maintaining exchange legitimacy, and instead, CSR reporting is seen as a mechanism to pursue consequential and structural forms of moral legitimacy.

The remainder of this paper proceeds as follows: Section 2 reviews the literature on CSR reporting in a developing countries context. Section 3 presents the theoretical framework utilised in this paper and how it links with the Egyptian context. Section 4 presents the research methods and methodology, and then the empirical results and discussion are presented in Section 5, followed by the conclusion, limitations and further work in Section 6.

\section{CSR reporting in developing countries}

CSR in developing countries has attracted significant attention over the last decade (Jamali et al., 2017; Hopper et al., 2017; Khan et al., 2020). One CSR research strand involves a gradual appreciation of the national/local-level motives and practices and their evolution from philanthropic motivations to more elaborate CSR strategies and logic (e.g. Jamali and Karam, 2016). Another strand of research considers the global and international drivers leading to the "transmission" of CSR to developing countries and involving the influence of large multinationals (e.g. Islam and Deegan, 2008; Belal et al., 2013; Islam and Kokubu, 2018) and international bodies and institutions, such as the World Bank, International Monetary Fund (UNECA, 2011), Global Reporting Initiative (GRI) and Integrated Reporting (IR). In the case of 
both research strands, CSR reporting practices reflect how companies engage with and are accountable to these different priorities, motivations and/or pressures (Gallhofer et al., 2011) and in turn has spurred a significant number of studies (e.g. Khan et al., 2020; Momin and Parker, 2013; Ali et al., 2017). Akin to financial accounting practice and corporate accountability principles, a core premise is that CSR reporting would enable the measuring, monitoring, and communicating of a company's commitment (and impact) on a range of social, environmental, and ethical issues. The voluntary and relatively unregulated nature of CSR reporting does, however, lead to large variations in CSR communication, and particularly so in the case of developing countries (Ali et al., 2017).

In this regard, a significant stream of CSR reporting studies (e.g. Mahadeo et al., 2011; Amran and Haniffa, 2011; Khan et al., 2020) in developing countries has emphasised the role of instrumental motivations (e.g. institutional theory, legitimacy theory and managerial stakeholder theory). CSR reporting is seen as a mechanism that communicates an organisation's congruence with societal objectives and expectations (Llewellyn, 2007), but there is considerable leeway in appreciating and interpreting what societal objectives and expectations might be from one context to another (De Villiers and Van Staden, 2006), and how this is perceived/communicated by organisational actors. In this way, CSR reporting becomes conceptualised as a mechanism companies rely upon to respond to dynamic social and institutional pressures and expectations to manage their legitimacy (De Villiers and Van Staden, 2006; Deegan and Unerman, 2006; Amran and Haniffa, 2011). A number of factors (e.g. firm characteristics, governance, ownership, external scrutiny, adoption of best practice standards) proxy for these legitimacy-led and stakeholder-led pressures, and in the main, these have been found to be significant on the basis of a number of cross-sectional studies in developing countries (e.g. Ali et al., 2017; Elshabasy, 2018; Kühn et al., 2018), including in Egypt. For example, Osman (2019) has investigated the CSR motivation of three Islamic banks in Egypt post-revolution and indicated that these banks have followed "an image enhancement strategy in the new Egyptian context after two revolutions to satisfy increasing social expectations" (p. 354). In the same vein, the political instability in Egypt following the 2011 revolution appears to encourage companies to disclose CSR activities as a "strategic tool to improve corporate image, to control policy and regulatory uncertainties, and to contain stakeholders' concerns" (El-Bassiouny and Letmathe, 2019, p. 14). Such conclusions thus remain wedded to instrumental-led stakeholder and legitimacy motivations.

Yet, and somewhat inherently, what has been less obvious from the above studies is how organisation-society relationships (Gray et al., 1995) are actually played out (or not), particularly in the case of "difficult" contexts and/or emerging social issues. For example, Belal and Cooper (2011) highlighted the absence of CSR reporting in relation to eco-justice areas of child labour, equal opportunities and poverty alleviation, due to limited resources, profit imperative and lack of regulations and awareness, and hence the lack of pressure on companies to report CSR practices on the themes. Similarly, Thompson and Zakaria (2004) refer to the lack of government and public pressures, as well as the lack of perceived benefits as the reasons for poor CSR reporting in Malaysia. More generally, stakeholder and other civil society groups may be marginalised or incapable of exercising pressure on companies (Egbon et al., 2018; Soobaroyen and Mahadeo, 2016; Darrag and Crowther, 2017), particularly when dealing with multinational entities (Lauwo et al., 2019). In other cases, shareholders and/ or managers are closely associated with state institutions and may engage in CSR practices and reporting at the bidding of politicians (Uddin et al., 2018). In a similar vein, Kamla (2007) argues that although social reporting is highly influenced by the political stance in the Arab Middle Eastern countries, it fails to offer a critical account of the sociopolitical realities in the region.

At the same time, CSR reporting may not be entirely borne out of a cynical ploy as many companies and owners are increasingly recognising the long-term benefits in contributing to 
AAAJ 34,5

1056

deficits in public services (e.g. Gallhofer et al., 2011; Amaeshi et al., 2016). In some developing countries, there is an expectation that CSR activities need to be more meaningful to address poverty, disease and hunger by integrating "societal concerns into. . .business policies and operations" (UNECA, 2011, p. 81). For instance, in response to the government's call to engage in long-term poverty alleviation projects instead of peripheral CSR activities, many local companies in a developing country (Mauritius) re-directed their efforts accordingly (Sannassee et al., 2017). In a similar way, a significant number of companies in developing countries have voluntarily engaged with CSR reporting international initiatives such as the United Nations Global Compact (UN Global Compact, 2019). These initiatives were designed to help organisations become more involved in solving "societal, social and ecological problems" (Idemudia, 2011, p. 1). Hence, there is scope for CSR reporting practices to act more broadly as a mechanism demonstrating the impact of companies as an integral part of the society, rather than merely as a "detached" entity serving its economic purposes (Amaeshi et al., 2016). In this light, seeking organisational legitimacy and legitimation not only implies adopting CSR reporting practices to meet transactional motives in response to the expectations of one's immediate audiences but also towards reflecting an appreciation of the broader responsibilities and purposes of the company in addressing deficits in the delivery of public services. However, in our view, there has been very little research on this aspect, both from the perspective of analysing CSR reports and exploring perceptions of organisational managers during, or close to, periods of significant sociopolitical changes (Darrag and Crowther, 2017).

We, therefore, seek to contribute to the CSR reporting literature by offering a different, albeit nuanced, analysis of the relevance of "political CSR" (Scherer and Palazzo, 2011) as an alternative or a co-existing motivation in the developing country context. This research chimes with calls to understand the CSR reporting motives in their native contexts and as a product of a unique interaction of institutional factors (Jamali and Karam, 2018). Since societal challenges differ (and are interpreted differently) from one context to another, it follows that CSR priorities, practices and reporting cannot follow a "one size fits all" approach (Darrag and E-Bassiouny, 2013; McWilliams and Siegel, 2000) when it comes to maintaining, gaining or repairing organisational legitimacy. This means that understanding the complexities and motivations behind CSR reporting practices requires an investigation that captures the "interplay of economic, political, legal, and normative institutions" (Blasco and Zølner, 2010, p. 246), which we address in our theoretical discussion and empirical study.

\section{Theoretical framework}

In this paper, we adopt a theoretical framework combining Scott's (2014) neo-institutional theory, Scherer and Palazzo's (2011) political CSR framework and Suchman's (1995) types of organisational legitimacy to analyse CSR reporting practices and to appreciate the motivations underlying organisational engagement with CSR and CSR reporting. While organisational legitimacy remains a key lens in the study of CSR reporting (Khan et al., 2020), our contention is that there remains an insufficient articulation of the linkages between Suchman's (1995) views on the "seeking" of legitimacy (i.e. organisation seeking to achieve a perceived congruence with the value system of a larger social system) and how/why do particular features of CSR reports contribute to the legitimation process and the types of legitimacy potentially being sought/achieved (Soobaroyen and Ntim, 2013; Vithana et al., 2019). In this respect, we argue that a combined theoretical framework can offer insights on the CSR reporting phenomenon, particularly when there are evolutions/changes to the value system(s) within the larger social system.

First, Scott's (2014) neo-institutional theory enables us to set out the institutional terrain within which motives for (or against) CSR and CSR reporting practices are articulated in a 
given national, region or sector. The role of institutions in influencing an organisation's engagement/disengagement with CSR practices has been discussed in the extant literature (Jamali and Neville, 2011; Muthuri and Gilbert, 2011; Li and Belal, 2018). The role of regulatory and normative institutional pillars in shaping CSR reporting practices is of particular interest (Scott, 2014) since institutional theorists have indicated that institutions "elide the distinction between organisations and their institutional environments by stressing the strong connection between processes occurring at societal (and even transnational) levels and the structure and operation of individual organisations" (Scott, 2014, p. 183). They emphasised the importance of the wider environment (Sandhu et al., 2012) and "the processes by which structures... including rules, norms, and routines, became established as authoritative guidelines for social behaviour" (Scott, 2005, p. 460). This perspective thus enables an understanding of prevalent socially constructed "value-systems" by taking into consideration the sociopolitical environment, and hence, uncovers how and why particular CSR and CSR reporting practices may be adopted.

Second, Scherer and Palazzo (2011) identify the characteristics associated with instrumental and political approaches to CSR. The authors support the notion that societal challenges cannot remain a problem left to the state, but rather non-state actors must become involved and play a political role to address governance deficits (Bradly and Nathan, 2019). For instance, Kühn et al. (2018) have relied on Scherer and Palazzo (2011) to analyse how country-level governance has a positive impact on CSR reporting in seven countries in SubSaharan Africa. In a similar realm, Barkemeyer et al. (2015) emphasises the role of government initiatives that complement the State's efforts in providing public goods and blur the lines between responsibilities of the private and public sectors. They have also shown that initiatives such as GRI played a role in motivating sustainability reporting in developing countries. Building on Scherer and Palazzo's (2011) work, Vigneau et al. (2015) demonstrated that the shift from national to global governance - embodied in (for example) the GRI or IR initiatives - can play a major role in shaping CSR in organisations, which tend to develop their own interpretation of how compliance with GRI (as a soft rule) is to be achieved. Finally, Wang and Li (2016) highlight that many private firms in China have assumed social and political roles beyond the confines of their economic mission, with state-owned companies facing higher expectations in terms of leading by example, i.e. on CSR reporting.

Scherer and Palazzo (2011) discuss the characteristics of a political vs. instrumental CSR approach in terms of a number of factors, including (and of relevance to the scope of this paper) the role of law, the governance model at national level and emphasising who can be considered the political actor (state vs. society and businesses). They have also stressed the role of the prevailing corporate governance model (shareholding vs. stakeholding or democratic corporate governance model). Table 1 summarises how these factors vary under the instrumental and political CSR approaches, according to Scherer and Palazzo (2011). This demonstrates the rich perspective that the integrated theoretical framework offers in facilitating an understanding of the settings in which the motives for CSR activities and reporting are instrumentally, as well as politically driven.

Finally, legitimacy refers to "a generalised perception or assumption that the actions of an entity are desirable, proper, or appropriate within some socially-constructed system of norms, values, beliefs, and definitions" (Suchman, 1995, p. 574). He identifies three main "dynamics" by which legitimacy can be sought or obtained: pragmatic, moral and cognitive. However, pragmatic and moral legitimacy are the most relevant in our discussion of CSR reporting since they are intimately linked to organisational communication, discursive evaluations (Suchman, 1995) and the establishment of a public dialogue between an organisation and its "relevant publics" (Soobaroyen and Ntim, 2013).

In the case of pragmatic legitimacy, the organisation seeks to cater for the demands of its most immediate audiences and this generally implies a transactional relationship between the 


\section{AAAJ 34,5}

1058
Characteristics

linked to the CSR

approach

Role of law

(n)

Table 1.

Characteristics of Instrumental v. Political CSR approaches national level

\section{Legitimacy} engagement

Instrumental CSR Political CSR

CSR is "rules-driven" (governmental regulation)

CSR associated to formal rules "hard rules" (e.g. on products, safety, employment)

Level of obligation High - often associated to compliance/enforcement

Precision of rules High

Governance model at Locus of National governance governance Role of economic rationality

\section{Dominance of short-term economic rationality}

Separation of political and economic spheres

Prevailing corporate governance model

Mode of corporate
High

\section{Shareholder-oriented}

High

Low

Passive / reactive; privileging of transactional relationships
CSR is driven by self-regulation

CSR is based on informal rules and "best practices"

Low- mostly voluntary

Low

Global, multi-level, and private governance

"Balancing" of economic and social rationalities for longterm growth and survival, i.e. using economic rationality as one of the criteria rather than the ultimate or primary criteria Low

Stakeholder-oriented and participative forms of governance

Medium-Low

Medium - High

Proactive (deeper engagement in social issues and activism)

Source(s): The authors, based on Scherer and Palazzo (2011, p. 908)

organisation and its relevant publics (Suchman, 1995). First, exchange legitimacy is concerned with a transfer of resources (financial or non-financial) in return for continued tangible or intangible benefits (for example, dividends, employee welfare or customer advantages). There is also an element of interdependence between the external audience and the organisation (Suchman, 1995), whereby organisational activities are scrutinised by the audiences to ensure that there are no adverse consequences to them (e.g. regulator, suppliers or customers). Influence legitimacy is a second form of pragmatic legitimacy, while not involving a transaction per se, but instead, audiences perceive the organisation to be responsive to their wider concerns. For instance, the adoption of a best practice guideline can convey a message that the company wishes to "...relinquish some measure of authority to the affected audience” (Suchman, 1995, p. 578). Finally, dispositional legitimacy occurs when an organisation is able to demonstrate its support for the broader concerns of the relevant public without necessarily adopting practices or guidelines. Overall, a common aspect of pragmatic legitimacy relates to the organisation's self-interested calculations (Suchman, 1995) about a given target audience and engaging in CSR practices to manage this audience and ensure its survival (Mahadeo et al., 2011). As such, this is closely linked to the notion of instrumental CSR.

In contrast, an organisational concern about moral legitimacy is based on judgements as to whether a specific organisational activity is the "right thing to do" (Suchman, 1995) and not 
on whether the activity will benefit the organisation or a given target audience. According to Suchman (1995, p. 579), "at its core, moral legitimacy reflects a prosocial logic that differs fundamentally from narrow self-interest" and because of the potential severe reputational damage that may arise from being "found out" (i.e. to be involved in cynical manipulations), organisations need to conform to principled ideals and be guided by questioning as to whether engaging in a particular practice will promote societal welfare. The three main forms of moral legitimacy are consequential, procedural and structural legitimacy. First, consequential legitimacy arises from an evaluation of the organisation's accomplishments and outputs, i.e. whether the organisation is delivering on what it is expected to achieve, and these outputs are socially constructed (i.e. whether in quantitative/qualitative terms). Second, procedural legitimacy is derived from the adoption of socially accepted techniques and procedures, and Suchman (1995) argues that following proper procedures and means can have a positive value even if there are no actual positive results. For instance, a firm may disclose the adoption of a policy on climate change to convey a form of procedural legitimacy irrespective of whether it has actually reduced climate change emissions. Thirdly, structural legitimacy involves the situation where the organisation adopts structures that convey the message that the organisation is "acting on collectively valued purposes in a proper and adequate manner" (Suchman, 1995, p. 581). In this case, legitimacy is garnered because some aspects of the organisational structure reflect intrinsic features that are worthy of support (e.g. setting up a charitable foundation). Overall, we would argue that these facets of moral legitimacy are rooted in broader concerns about the organisation's perceived role in society and thus more in line with the notion of political CSR.

In conclusion, and as per Table 1, our framework combines the neo-institutional approach, Scherer and Palazzo's (2011) notions of the instrument and political CSR and Suchman's (1995) concepts of pragmatic/moral legitimacy to conceptualise corporate approaches (and changes) to CSR reporting. It is important here to note that the notion of legitimacy can be seen as a property or a resource that can be obtained by organisations, or as an interactive process (Suddaby et al., 2017). In this way, CSR reporting can be strategically sought and/or it can also as part of a wider interactive process involving the organisation's perceptions of its (changing) role within society. In the "process" of achieving moral legitimacy, we contend that businesses take a more active role in CSR in line with the tenets of political CSR. At the same time, our framework is dependent on an understanding of organisational legitimacy that is not static or universally defined, which is subject to the peculiarities of a given context. There is, therefore, a need to articulate how the changes in the Egyptian context (with a focus on the banking sector) might have impacted CSR and CSR reporting. We do so after explaining our data and methodological considerations.

\section{Data and research methodology}

We adopt a two-stage approach for the data collection. First, and consistent with many prior studies (e.g. De Villiers and Van Staden, 2006; Amran and Haniffa, 2011; Soobaroyen and Mahadeo, 2016), we carry out a content analysis of banks' web disclosures (including its annual reports [2]) to ascertain "factually" the nature of CSR themes and activities undergone by the banks, and any change over time, with a particular emphasis (and link to) the 2011 revolution. Our research identified 40 banks that operated in Egypt during the periods under review $(2013$; 2016) as listed by the CBE. A review in 2013 showed that approximately $48 \%$ (19) of the banks published CSR information on their respective websites, and this increased to $65 \%$ (26) in 2016 [3].

Second, and somewhat distinctively, we draw on interviews to further tease out the implications of the change in societal expectations due to the revolution, and deepen our understanding of the organisational/managerial motivation for CSR reporting in light of the 
AAAJ 34,5

1060 initial insights we gathered from the content analysis of the CSR disclosures. As often highlighted by some researchers (O'Dwyer, 2004; Islam and Deegan, 2008; Belal and Cooper, 2011; Li and Belal, 2018), field studies and interviews of relevant actors enable the gathering of more nuanced legitimacy-based explanations of CSR reporting patterns (including the absence of reporting) to supplement the "big picture" that emerges from the annual reports. These two stages were performed in 2013 (Round 1) and again in 2016 (Round 2) to account for the transitions arising from the political, economic and social change in Egypt, which began in 2011 and continued afterwards. An overall summary of the research approach is provided in Appendix 2. An explanation of the sample used and the methods employed is now provided.

\subsection{Content analysis}

Content analysis involves the classification of textual information using a detailed set of protocols and coding (Boyatzis, 1998; Bryman and Bell, 2015). While many studies can use word counts or sentence counts or even the proportion of a page (Beattie et al., 2004) to measure the volume of disclosure, we relied on a disclosure checklist to capture CSR themes (Cho and Patten, 2007; Hooks and Van-Staden, 2011). Since disclosure remains fairly limited in Egypt, we privileged a simpler approach to record presence/absence of disclosure, as opposed to devising a sophisticated disclosure checklist that might be more applicable to the case of companies in developed countries or those adopting elaborate standards of reporting (e.g. Global Reporting Initiative, Integrated Reporting).

Informed by prior literature on CSR in developing countries (e.g. Wanderley et al., 2008; Zhu and Zhang, 2015; Jain et al., 2016; Kilic, 2016), the coders considered and agreed on 37 disclosure items. These items/themes were further coded by interpreting each disclosure item as to whether it might be related to an instrumental or political CSR approach (Scherer and Palazzo, 2011), and by extension, how these might be associated with a pragmatic or moral form of legitimacy (Suchman, 1995). In particular, political CSR disclosures were identified as those where banks were aiming to address broader concerns (environment) and deficits in public services, e.g. health, education and poverty alleviation. In contrast, instrumental CSR disclosures were aimed more at the managing of traditional stakeholders (regulators, customers, and employees), as applicable to the local context.

One issue that often arises with disclosure indices is whether certain items are more important than others and thus should be weighted accordingly (see Marston and Shrives, 1991). However, there are a number of issues with weighting, including that the importance of individual items may vary according to different users, and adding weights inevitably adds to the subjectivity of an index. Consequently, the authors did not weight items, apart from two for which different scores were given where either the disclosure was detailed (environmental policy) or reporting was more regular (sustainability report). To have weighted other items would have made the index much more subjective, whereas these two items were relatively objective. The coders used a spreadsheet to record their scores, and items for which there was disagreement were flagged. According to Milne and Adler (1999), in relation to inter-rater reliability, the majority of disagreements relate to how an item/theme should be coded. Where there was disagreement, each coder was asked to revisit these items, and a discussion was held to reach a final agreement. The agreement percentage was calculated using Cohen's Kappa (Stemler, 2001) with an agreement rate (after adjusting for agreement by chance) of $91.86 \%$, representing a high level of agreement (Landis and Koch, 1977). The final categories are shown in Table 2 and Table 3 , together with the disclosure item and a justification as to the reason for the categorisation. The details of specific disclosures included according to legitimacy type targeted are summarised in Table 4 and detailed, as shown in Appendix 3. 


\begin{tabular}{|c|c|c|c|}
\hline $\begin{array}{l}\text { Instrumental or political } \\
\text { approach to CSR }\end{array}$ & Item & $\begin{array}{l}\text { Legitimacy type from Suchman } \\
\text { (1995) }\end{array}$ & disclosures in \\
\hline Instrumental & $\begin{array}{l}\text { Any reference to guidelines (OESO or } \\
\text { World Bank) }\end{array}$ & $\begin{array}{l}\text { Pragmatic - Demonstrate high } \\
\text { CSR standards }\end{array}$ & countries \\
\hline Instrumental & Quantitative targets & $\begin{array}{l}\text { Pragmatic - Demonstrate high } \\
\text { CSR standards }\end{array}$ & \\
\hline Instrumental & Supply chain reference & $\begin{array}{l}\text { Pragmatic - Demonstrate high } \\
\text { CSR standards }\end{array}$ & 1061 \\
\hline Instrumental & Financial literacy & $\begin{array}{l}\text { Pragmatic- Attract new segment } \\
\text { of customers }\end{array}$ & \\
\hline Instrumental & Responsible Shariah products & $\begin{array}{l}\text { Pragmatic- Attract new segment } \\
\text { of customers }\end{array}$ & \\
\hline Instrumental & Socially responsible Investments & $\begin{array}{l}\text { Pragmatic- Attract new segment } \\
\text { of customers }\end{array}$ & \\
\hline Instrumental & Socially responsible saving & $\begin{array}{l}\text { Pragmatic- Attract new segment } \\
\text { of customers }\end{array}$ & \\
\hline Instrumental & Special help for employees & Pragmatic- Managing Employees & \\
\hline Instrumental & Staff volunteering time & Pragmatic- Managing Employees & \\
\hline Instrumental & Employee training & Pragmatic- Managing Employees & \\
\hline Instrumental & Work/life balance & Pragmatic- Managing Employees & \\
\hline Instrumental & Employee staff survey & Pragmatic- Managing Employees & \\
\hline Instrumental & Political giving & $\begin{array}{l}\text { Manage relationships with key } \\
\text { stakeholders }\end{array}$ & \\
\hline Instrumental & Formal charter adopted & $\begin{array}{l}\text { Manage relationships with key } \\
\text { stakeholders }\end{array}$ & \\
\hline Instrumental & Prompt payment & $\begin{array}{l}\text { Manage relationships with key } \\
\text { stakeholders }\end{array}$ & \\
\hline Instrumental & Whistle blowing procedures & $\begin{array}{l}\text { Manage relationships with key } \\
\text { stakeholders }\end{array}$ & \\
\hline Instrumental & Discussion of CSR plans & $\begin{array}{l}\text { Manage relationships with key } \\
\text { stakeholders }\end{array}$ & \\
\hline Instrumental & $\begin{array}{l}\text { Anti-corruption / money laundering } \\
\text { rules }\end{array}$ & $\begin{array}{l}\text { Manage relationships with key } \\
\text { stakeholders }\end{array}$ & $\begin{array}{r}\text { Interpretation of } \\
\text { instrumental }\end{array}$ \\
\hline Source(s): The authors & & & pragmatic disclosures \\
\hline
\end{tabular}

\subsection{Interview process and analysis}

Gaining access to participants with the appropriate CSR experience and profile, particularly in relation to the banking sector, was challenging, thereby requiring authors to rely on their professional networks, social media platforms (e.g. "LinkedIn") to identify individuals, and snowball sampling (e.g. Tremblay and Gendron, 2011). From an initial contact with 25 potential participants, 12 agreed to be interviewed in 2013 (eight of whom consented to be reinterviewed in 2016 in addition to a new participant) and comprised of current senior bank managers, CSR managers, CSR academics/consultants and government officials with strong knowledge of banking regulations. In spite of guarantees of confidentiality and anonymity, none of the interviewees agreed to an audio recording. Bank managers in Egypt (and local participants more generally) are understandably cautious about being interviewed by academics. Instead, notes were made and read at the end of each interview to ensure an accurate record of the insights. Since most participants were interviewed twice, this offered an opportunity to ensure an appropriate representation of their opinions. In this research, we utilised the following strategies to ensure credibility in line with Lincoln and Guba (1985), namely: (1) Prolonged engagement in the field as the first stage of interviews took place in 2013, while the second stage took place in 2016. (2) Triangulation, where we used multiple and 


\begin{tabular}{|c|c|c|c|}
\hline $\begin{array}{l}\text { AAAJ } \\
34,5\end{array}$ & & Item & $\begin{array}{l}\text { Legitimacy type from Suchman } \\
\text { (1995) }\end{array}$ \\
\hline \multirow[b]{3}{*}{1062} & Political & Donations to healthcare & $\begin{array}{l}\text { Moral - Addressing gaps in public } \\
\text { services (healthcare) }\end{array}$ \\
\hline & Political & Donations to the needy & $\begin{array}{l}\text { Moral - Addressing gaps in public } \\
\text { services (healthcare) }\end{array}$ \\
\hline & Political & Donations to education & $\begin{array}{l}\text { Moral - Addressing gaps in public } \\
\text { services (healthcare) }\end{array}$ \\
\hline \multirow{17}{*}{$\begin{array}{l}\text { Table } 3 . \\
\text { Interpretation of } \\
\text { Political moral } \\
\text { disclosures }\end{array}$} & Political & $\begin{array}{l}\text { Establishing foundations for } \\
\text { community development }\end{array}$ & $\begin{array}{l}\text { Moral - Addressing gaps in public } \\
\text { services (healthcare) }\end{array}$ \\
\hline & Political & Arts/culture & Moral - Contributing to Arts/culture \\
\hline & Political & Social rules & Moral - Meet society expectations \\
\hline & Political & Diversity declaration & Moral - Promote human rights \\
\hline & Political & Diversity targets & Moral - Promote human rights \\
\hline & Political & Human rights & Moral - Promote human rights \\
\hline & Political & $\begin{array}{l}\text { Discussion of environmental issues } \\
\text { (water/air) }\end{array}$ & $\begin{array}{l}\text { Moral- Protect the environment and } \\
\text { adopt sustainability }\end{array}$ \\
\hline & Political & $\begin{array}{l}\text { Environmental risk management in } \\
\text { lending policy }\end{array}$ & $\begin{array}{l}\text { Moral- Protect the environment and } \\
\text { adopt sustainability }\end{array}$ \\
\hline & Political & $\begin{array}{l}\text { Environmental rules concerning new } \\
\text { business }\end{array}$ & $\begin{array}{l}\text { Moral- Protect the environment and } \\
\text { adopt sustainability }\end{array}$ \\
\hline & Political & Environmental advice service & $\begin{array}{l}\text { Moral- Protect the environment and } \\
\text { adopt sustainability }\end{array}$ \\
\hline & Political & Environmental policy & $\begin{array}{l}\text { Moral- Protect the environment and } \\
\text { adopt sustainability }\end{array}$ \\
\hline & Political & Climate change products & $\begin{array}{l}\text { Moral- Protect the environment and } \\
\text { adopt sustainability }\end{array}$ \\
\hline & Political & Any certification or audit & $\begin{array}{l}\text { Moral- Protect the environment and } \\
\text { adopt sustainability }\end{array}$ \\
\hline & Political & Sustainability report & $\begin{array}{l}\text { Moral- Protect the environment and } \\
\text { adopt sustainability }\end{array}$ \\
\hline & Political & $\begin{array}{l}\text { Environmental listing/bench } \\
\text { marking }\end{array}$ & $\begin{array}{l}\text { Moral- Protect the environment and } \\
\text { adopt sustainability }\end{array}$ \\
\hline & Political & Sustainable finance & $\begin{array}{l}\text { Moral- Protect the environment and } \\
\text { adopt sustainability }\end{array}$ \\
\hline & Source(s): The authors & & \\
\hline
\end{tabular}

different sources of data (online disclosures, interviews and documents), investigators (two coders) and theories (refer to our combined theoretical framework). The interviewee profiles are summarised, along with the main questions discussed, in Appendix 2. Bank managers were asked for their views in context of the publicly available online disclosures made by their bank/other banks. In addition, the authors interviewed CSR managers, CSR academics/ consultants and government officials to gain more insights into the institutional settings and evolution thereof. Data were collected by the first author, who is an Egyptian and has experience of working in the Egyptian business environment for over 14 years.

Interview data were analysed using qualitative content analysis (QCA) (Schreier, 2012), which is defined, i.e. "a research method for the subjective interpretation of the content of text data through the systematic classification process of coding and identifying themes or patterns" (Hsieh and Shannon, 2005, p. 1278). The focus here is the "latent meaning" of participants' views taking into consideration the broader context, namely the institutional environment and banks' CSR disclosures. While we paid attention to participants' views, our theoretical framework combining neo-institutional theory, political/instrumental CSR and 
Suchman's (1995) types of pragmatic and moral legitimacy informed our analysis of the interview data (Collins and Stockton, 2018, p. 6). Analysing CSR disclosures ahead of interviews also enabled the researchers to ask relevant and contextualised questions to tease out the organisational and managerial motivation for engaging in CSR and providing CSR disclosures. The QCA process was hence applied to each interview notes to derive categories based on a "thematic criterion" driven by both data and theory (Schreier, 2012, p. 136). In practice, this requires the researchers to synthesise and interpret every interview in relation to a particular theme or category (e.g. neo-institutional pressures (regulatory and normative), political CSR, instrumental CSR, and Suchman's (1995) different types of legitimacy (exchange, consequential and procedural).

\section{Findings and discussion}

\subsection{Emergence of CSR norms within the Egyptian context}

In this section, we address how the recent changes in the Egyptian institutional environment, including the socioeconomic and political landscape and how these changes led to the evolution of norms, rules and routines with regards to CSR and CSR reporting. While Egypt is the second-largest economy in Africa, in terms of GDP (Purchasing Power Parity), and the 28th largest in the world (CIA, 2015), it has faced significant challenges over the last fifty years mainly due to inconsistent and unclear economic planning borne out of (often radical) changes in political systems, governance and leadership. After experimenting with a socialist centrally planned system in the 1960s, the country underwent a series of neoliberal reforms from the mid-1970s to open up its economy, attract foreign direct investment and foster private sector growth - with very mixed results (CIA, 2015). For instance, during the period 2004-2009, some of these structural reforms delivered modest economic growth (nearly 6\%), but they did not translate into social gains "primarily due to corruption and lack of political reform" (Sherif and Sharara, 2016, p. 4). High levels of poverty persisted, with $26.3 \%$ of Egyptians living below the national poverty line (Muthuthi, 2014), a 13.4\% unemployment rate in 2013, a poor and fragmented social protection system, a highly criticised education system and an inefficient national healthcare system (CIA, 2015). This state of affairs was further worsened by the global financial crisis and a consequent rise in unemployment and inflation rates (Kenawy and Abd-El Ghany, 2012).

Unsurprisingly perhaps, these persisting issues, alongside a democratic deficit, contributed to the 2011 revolution, under the slogans of "bread" (aish), "freedom" (hurriyya) and "human dignity (karamainsaniyya)... (that is) democracy and social justice (Teti and Gervasio, 2011, p. 323). The revolution also put a spotlight on the role of the private sector in terms of their limited contribution to addressing chronic local issues and a growing realisation among companies that more proactive social engagement will be required to "focus on issues in key sectors of direct relevance to national growth and development such as education, health, and economic opportunity" (Avina, 2013, p. 81). For example, one participant indicated that "CSR is important for the financial sector to regain trust especially with the current political scene (Participant 6, 2013). Other examples of the importance of engagement with society include," marginalised people need things to improve their quality of life... not money. They need better drinking water, access to good healthcare etc." (Participant 5, 2013).

Given the heightened societal aspirations for change post-2011, a normative expectation developed whereby everyone, including businesses, has to contribute financially to support the country and help ease the current tough economic and social conditions. After the revolution, "People feel [sic] a sense of ownership for their country that they never had. If there is a problem in their country, they now know they have the responsibility to fix it" (Avina, 2013, p. 82). According to Darrag and Crowther (2017, p. 109), there is a sense of "social duty. . of the 


\section{AAAJ 34,5}

\begin{tabular}{|c|c|c|c|c|c|c|c|c|c|c|}
\hline \multirow{2}{*}{$\begin{array}{l}\text { Instrumental } \\
\text { or political } \\
\text { approach to } \\
\text { CSR } \\
\end{array}$} & \multirow{2}{*}{$\begin{array}{l}\text { Legitimacy } \\
\text { type from } \\
\text { Suchman } \\
\text { (1995) }\end{array}$} & \multicolumn{3}{|c|}{$\begin{array}{l}2013 \\
\text { \% of banks } \\
\text { disclosing }\end{array}$} & \multicolumn{3}{|c|}{$\begin{array}{c}2016 \\
\% \text { of banks } \\
\text { disclosing }\end{array}$} & \multicolumn{3}{|c|}{$\begin{array}{l}\% \text { Change from } 2013 \text { to } \\
2016^{* * * *} \\
\% \text { of banks disclosing }\end{array}$} \\
\hline & & LP* & $\mathrm{S}^{* *}$ & $\mathrm{~F}^{* * * *}$ & LP & S & $\mathrm{F}$ & LP & S & $\mathrm{F}$ \\
\hline Instrumental & $\begin{array}{l}\text { Pragmatic - } \\
\text { Demonstrate } \\
\text { high CSR } \\
\text { standards }\end{array}$ & $0 \%$ & $11 \%$ & $13 \%$ & $17 \%$ & $22 \%$ & $13 \%$ & + & $100 \%$ & $0 \%$ \\
\hline Instrumental & $\begin{array}{l}\text { Pragmatic- } \\
\text { Attract new } \\
\text { segment of } \\
\text { customers }\end{array}$ & $17 \%$ & $33 \%$ & $25 \%$ & $19 \%$ & $33 \%$ & $22 \%$ & $13 \%$ & $0 \%$ & $-13 \%$ \\
\hline Instrumental & $\begin{array}{l}\text { Pragmatic- } \\
\text { Managing } \\
\text { Employees }\end{array}$ & $10 \%$ & $33 \%$ & $24 \%$ & $8 \%$ & $27 \%$ & $28 \%$ & $-25 \%$ & $-20 \%$ & $17 \%$ \\
\hline Instrumental & $\begin{array}{l}\text { Manage } \\
\text { relationships } \\
\text { with key } \\
\text { stakeholders }\end{array}$ & $22 \%$ & $17 \%$ & $28 \%$ & $29 \%$ & $61 \%$ & $34 \%$ & $32 \%$ & $267 \%$ & $22 \%$ \\
\hline Total & & $14 \%$ & $24 \%$ & $24 \%$ & $19 \%$ & $39 \%$ & $26 \%$ & $35 \%$ & $62 \%$ & $10 \%$ \\
\hline Political & $\begin{array}{l}\text { Moral - } \\
\text { Addressing } \\
\text { gaps in public } \\
\text { services } \\
\text { (healthcare) }\end{array}$ & $54 \%$ & $83 \%$ & $53 \%$ & $59 \%$ & $92 \%$ & $67 \%$ & $10 \%$ & $10 \%$ & $27 \%$ \\
\hline Political & $\begin{array}{l}\text { Moral - } \\
\text { Contributing } \\
\text { to Arts/culture }\end{array}$ & $17 \%$ & $67 \%$ & $30 \%$ & $25 \%$ & $67 \%$ & $40 \%$ & $50 \%$ & $0 \%$ & $33 \%$ \\
\hline Political & $\begin{array}{l}\text { Moral - Meet } \\
\text { society } \\
\text { expectations }\end{array}$ & $0 \%$ & $0 \%$ & $20 \%$ & $0 \%$ & $67 \%$ & $20 \%$ & $0 \%$ & + & $0 \%$ \\
\hline Political & $\begin{array}{l}\text { Moral - } \\
\text { Promote } \\
\text { human rights }\end{array}$ & $6 \%$ & $0 \%$ & $13 \%$ & $4 \%$ & $33 \%$ & $13 \%$ & $-25 \%$ & + & $0 \%$ \\
\hline Political & $\begin{array}{l}\text { Moral- Protect } \\
\text { the } \\
\text { environment } \\
\text { and adopt } \\
\text { sustainability }\end{array}$ & $5 \%$ & $10 \%$ & $18 \%$ & $14 \%$ & $27 \%$ & $19 \%$ & $175 \%$ & $167 \%$ & $7 \%$ \\
\hline Total & & $16 \%$ & $26 \%$ & $25 \%$ & $22 \%$ & $46 \%$ & $29 \%$ & $38 \%$ & $73 \%$ & $17 \%$ \\
\hline
\end{tabular}

\section{Table 4.}

Summary of average instrumental and political disclosures in 2013 and 2016 by the three bank types
Source(s): The authors; *LP: Local Private Banks; **S: State Banks; ***F: Foreign Banks; **** all figures are rounded, hence may not correspond with the sum of the separate figures; + denotes an increase from zero percent

corporation toward their communities". One participant commented that CSR is equivalent to "nationalism ... the social role of banks is paramount, it gives more confidence in the country and the economy... CSR requires banks to invest in the society" (Participant 5, 2016). Another informant added, "Credit facilities financing projects with a greater social impact are favourably looked at by the CBE" (Participant 3, 2013). Finally, another participant commented, "in the past CSR was business excellence but [now has] developed to really paying back to the community" (Participant 6, 2013).

Furthermore, the new political regime, led by President El Sisi, sought to shape a new relationship with businesses and communities. The government called upon citizens to donate their spare change to fund charitable projects, which despite criticism (BBC, 2016a) 
has received support as an innovative solution to the troubled economy (BBC, 2016b). In a similar vein, the Egyptian government created the "Long Live Egypt" (LLE) fund that managed to collect, within 18 months, nearly 5 billion Egyptian Pounds [4] (EGP) (Egypt Independent, 2016), with some social development projects entirely financed by a consortium of businesses and banks. One relevant example is the Bashayer El-Khier project, financed principally by a consortium led by the National Bank of Egypt and involving a donation of 150 million EGP (Farouk, 2016) [5]. In effect, it appears there has been a major shift in Egyptian government policy towards embedding the private sector in the delivery of development other public services, as evidenced by this official report by the Egyptian Ministry of Trade and the Industrial Modernization Centre:

It is clear that Egypt has very little time to waste in attempting to achieve both stability and sustainable growth. Neither traditional capitalism nor traditional development paradigms are an answer anymore. . . Involving the private sector as a key stakeholder in the sustainable development of Egypt is no longer something to question or debate (Sherif and Sharara, 2016, p. 4).

Against this background, we argue that there has been a gradual shift in Egypt towards a new social and political reality, whereby businesses are stepping in and contributing to the public arena, and hence seen to be operating as political rather than merely economic actors (Scherer and Palazzo, 2011). Rather than seeing these changes as a strategic pressure from the state and society, we instead conceive of these developments as a deeper change in the authoritative guidelines of social behaviour (Scott, 2005) and in the value systems concerning what is expected of companies in Egypt. Such normative forces "introduce a prescriptive, evaluative, and obligatory dimension into social life" (Scott, 2014, p. 64), thereby leading to the emergence of a CSR norm for businesses to act beyond economic rationality [6]. These institutional changes set the scene for CSR and CSR reporting policies in the banking sector post-2011.

5.1.1 CSR regulations and the role of pioneer banks within the Egyptian banking system. The banking sector was viewed as a major player to establish CSR engagement and reporting in the business environment given that it provides $85 \%$ of business financing in Egypt (El-Said, 2009; Scholtens, 2009). To this effect, the CBE issued governance instructions (henceforth "code") in 2011 requiring banks to disclose their CSR policies and practices, thus making it explicit that banks are expected to be engaged in CSR in a transparent manner. However, many participants felt compliance with the code was not the decisive factor in motivating banks to report their CSR activities, but there were other instrumental motives in place. In relation to this point, one participant dismissed the influence of the code, stating, "No, codes have no impact at all, different factors are evident here" (Participant 7, 2013). Another participant opined that the code can just "encourage philanthropy as when you pay to charity you get a tax deduction" (participant 4, 2013). These comments appear to relegate the role of the code in motivating CSR disclosures, albeit that they do not completely dismiss its influence.

Furthermore, with a number of MNCs headquartered in developed countries operating in Egypt, such as Barclays Bank [7], AlexBank and Credit Agricole, these companies played an important role in establishing practices such as CSR reporting; a common practice in their home offices (El-Kayaly, 2014). Also, given staff mobility between different banking organisations within the EBS, practices such as CSR reporting were diffused as domestic banking organisations begin to mimic foreign banks in terms of their perceived highefficiency reporting and up-to-date practices. A few domestic banks, such as the Commercial International Bank (e.g. CIB), have become a pioneer in setting a good example in CSR in general and in relation to reporting in particular. $\mathrm{CIB}$ has established the $\mathrm{CIB}$ foundation [8] to focus on health, education and nutritional services for unprivileged children. This move from MNCs and pioneer banks reveals a deeper engagement since they were taking responsibility 
AAAJ 34,5

1066

for the "social and environmental externalities to which they are connected" (Scherer and Palazzo, 2011, p. 907). This marked a shift from seeing CSR as a liability or burden to be being part of the social connectedness. Here, many participants agreed that "CSR engagement and disclosure depends on bank ownership, i.e. whether it is foreign or domestic" (participant 8, 2013) and the level of "senior management awareness and support of the CSR agenda" (participant 8, 2013).

\subsection{Evolution of CSR disclosures}

The section summarises the findings in relation to the CSR disclosures from 2013 to 2016. A summary of the main changes from 2013 to 2016 is shown in Table 4 [9] depicting the main themes and items disclosed by the percentage of banks in total and split by the type of banks, i.e. Local Private (LP), State (S) and Foreign. In line with our interpretive scheme, we classify the disclosure items and themes in relation to Scherer and Palazzo's instrumental/political CSR approaches and the respective types of legitimacy (pragmatic and moral). The emphasis of the disclosures in 2013 can primarily be classified as instrumental and aimed at a pragmatic type of legitimacy. In particular, as a result of the $2011 \mathrm{CBE}$ code's requirements in relation to the disclosure of CSR plans, all banks disclosed accordingly while some of them referred to additional guidelines in an attempt to demonstrate adherence to high CSR standards as indicated by the regulator's (CBE) rules. A further consideration of the regulator's concerns on ethics and banking practices can also be noted with an increased prevalence of disclosures on aspects such as money laundering rules and whistleblowing procedures from 2013 to 2016. Furthermore, since pragmatic legitimacy indicates the management of its most immediate audiences with an emphasis on economic exchanges, there was an increase in disclosures relating to financial literacy, socially responsible investments/savings, and responsible Shariah products.

It has been previously suggested that early attempts at engaging with CSR activities in developing countries (Mahadeo et al., 2011; Soobaroyen and Mahadeo, 2016) were often (narrowly) associated with the business activity or purpose of the company and hence driven by an economic rationale, e.g. disclosure of CSR activities to protect beaches by hotel companies or provision of loans for social housing purposes by banks. In the Egyptian case, we note that disclosures in relation to financial literacy and responsible investment/savings disclosures have been increasing, and this can be interpreted as a strategy to attract new customers. Last, employee-related disclosures (special help for employees, staff volunteering time, employee training and work-life balance) are notable across the sample of banks and are suggestive of an instrumental concern in satisfying the expectations of an important (human) resource and ensure the continued provision of banking services. Overall, CSR disclosures that are deemed instrumental and aimed at securing pragmatic legitimacy have increased over time. These involve an increased coverage of themes that appeal to specific and immediate audiences (regulators/local rules, customers and employees) while privileging transactional relationships. At the same time, some specific variations in instrumental CSR disclosures are observed with regard to the types of banks. In particular, state-owned banks seemed keener, relative to local private and foreign banks, to engage on a broader set of CSR disclosures aimed at managing stakeholders (e.g. political donations, formal charter, money laundering rules, whistleblowing procedures, and adherence to guidelines). This is arguably reflective of a changing and potentially uncertain social and political landscape, requiring state-owned banks to demonstrate a "closer" relationship with specific audiences (e.g. regulators, government decision-makers). In this respect, their managers may perceive the need to disclose more on these themes to maintain pragmatic legitimacy relative to local private banks and foreign banks. 
In parallel, the implications of the changing landscape (role of the private sector in Egypt and national calls to support the country) have become noticeable in terms of what we classify as political CSR disclosures. First, the extent to which banks report on supporting public service actions (donations towards healthcare, poverty, education and arts/culture) have increased, inclusive of the practice of setting up charitable foundations. For instance, more than $50 \%$ of the banks disclose their involvement in addressing gaps in education and healthcare services. The proportion of banks reporting on the establishment of foundations has almost doubled from 2013 to 2016 (28\%). Second, the protection of the environment and embedding of sustainability principles appears to be given more priority, with a third of banks now providing details of their environmental policy and nearly a quarter reporting on environmental risk management aspects relating to their lending practices. We argue that these illustrate an appreciation of the need to balance economic, as well as social (environmental) imperatives in line with Scherer and Palazzo's (2011) view of political CSR. Corporate disclosures about the effects of business/ corporate activities on the environment are known to fluctuate widely across developing countries (e.g. De Villiers and Van Staden, 2006; Mahadeo et al., 2011; Khan et al., 2020), due to (economic) development priorities, the controversial nature of some industries (e.g. oil, mining) and the links to the wider phenomenon of climate change. Notwithstanding, and while there is relatively little in the way of regulatory pressure (i.e. CBE) to consider these specific aspects, we argue that these disclosures arise from a deeper consideration and engagement by banks on their social role post-2011, and in light of the re-positioning of the private sector as an important player in addressing the development challenges faced by Egypt post-2011. These disclosures, therefore, reflect an emerging trend of seeking to do the "right thing" and adopting a pro-social approach to gain moral legitimacy (Suchman, 1995).

When considering disclosures by the different types of banks, local, state and foreign banks all appear to have reflected on the need to address the gaps in public services (healthcare, education and poverty). At the same time, the proportion of disclosing stateowned banks is the highest relative to other types of banks not only in relation to the provision of public services but also when considering other themes such as establishing foundations, arts/culture, environmental policy/risk management and the provision of sustainability reports. Furthermore, this higher level of commitment to political CSR is noted, even in the context of pro-social "activist" themes, namely in the promotion of human rights (diversity declaration disclosures and social rules). Typically, state banks cater to the less economically advantaged people in the community and on a wider regional basis. For example, Banque Misr (a leading state bank), focused on enhancing financial inclusivity through reaching out with banking services and participating in mortgage initiatives targeting the unprivileged and middle-income individuals. Banque Misr has also financed another microfinance initiative called "Mashroai-Mashroak" (translated in English as "your project") aimed at achieving community development through supporting micro and small enterprises (Banque Misr, 2020). Therefore, these banks seem to display a higher level of affiliation to the new national development ethos and initiatives arising from the 2011 revolution and the extant government leadership. Conversely, foreign banks appear less inclined to provide other types of political CSR disclosure, potentially as a result of the diverging priorities set by the foreign owners/headquarters.

In summary, we note that a higher proportion of banks in Egypt have shifted their CSR disclosures from a narrower set of instrumental, transactional-led, CSR themes (aimed at pragmatic legitimacy) towards encompassing a wider set of political CSR themes that are aimed at achieving moral legitimacy. Of particular note is that the change in disclosures is more noticeable for state-owned banks than more local private or foreign banks. This evolution can be associated with the changing social and political landscape as to the role of

\section{CSR \\ disclosures in developing countries}

1067 
AAAJ

34,5

1068

the private sector in the post-2011 revolution, both of in terms of changing societal expectations and recognition by the sector of its own (wider) responsibilities to the country.

While our theoretically informed analysis of the disclosures highlights the blend of pragmatic and moral legitimacy motivations arising respectively from an instrumental and political CSR perspective, what is less clear is the discrete forms of these pragmatic and/or moral legitimacy arguments. Prior research (e.g. Soobaroyen and Ntim, 2013; Jamali and Karam, 2016) suggests that insights from relevant organisational representatives may be useful in appreciating the dynamics underpinning political CSR and its reporting, particularly in the context of a changing environment. We, therefore, explore this point further in the next section.

\subsection{Emerging motivations about CSR reporting}

The next section presents and discusses the empirical findings in relation to the interview data. Guided by our theoretical framework, we highlight the key insights associated with an organisational and managerial concern in re-prioritising CSR reporting as a mechanism of political CSR and maintaining/gaining moral legitimacy. We identify key three categories relevant to our research question, namely CSR reporting as a means to acknowledge sociopolitical change, emphasis on the pursuance of consequential legitimacy, and the rise of charitable foundations and structural legitimacy.

First, from the interviews, some participants concurred that a number of regulative and normative pressures previously had sought to institutionalise the process of CSR reporting, and in particular, the CBE's requirement in 2011 to all banks to disclose their CSR policies and practices. However, and while our content analysis suggested a notable increase in disclosure levels across banks, our informants were not convinced that the regulation on its own translated into deeper levels of CSR involvement. For example, it was mentioned that "There is a code, but I cannot remember that someone from the CBE has ever asked about it" (Participant 9, 2013). Similarly, another participant added, "I do not think that CSR is a priority for the EBS at the moment, given the sheer economic troubles they are handling. For the CBE, the first, second and third priority is the economic reform programme, CSR reporting is a decoration on the cake" (Participant 4, 2016). Finally, another participant 8 (2016) stated, "No, codes do not have much impact here, different factors are more evident". These responses appear to reflect a more varied and somewhat instrumental view towards CSR reporting and in line with a pragmatic legitimacy approach of modestly engaging with the most immediate audiences to ensure the organisation is positioned "within a pre-existing institutional regime" (Suchman, 1995, p. 587). In particular, reference was made to the case of local private banks that traditionally associated (limited) CSR activities with financial constraints. In this respect, one participant stated, "Charitable contributions are fixed, subject to the approval of the general assembly, so you cannot really do what you want because how will you convince the shareholders?" (Participant 2, 2013). Similarly, another participant added, "some time ago, I suggested an excellent project for true CSR, it was related to supporting a particular hospital. I was disappointed to be told 'please do not repeat these suggestions again, you are a senior manager and should know this will not be approved'... this will eventually mean less to report, but in fairness this was before the 2011 revolution, now things have changed slightly" (Participant 1, 2016). Hence, in many cases, there remains a strategy of pursuing an exchange legitimacy by supporting selected and most immediate audiences (i.e. philanthropy and charity donations) and limited CSR reporting themes.

Contrastingly, and rather more significantly, many interviewees argued that the post 2011-revolution context, marred by concerns about unemployment, chronic deficiencies in public services and the limited role of the private sector in addressing these challenges, disrupted the traditional strategy of "peripheral" or "mild" conformance to CSR and its 
reporting. For example, Participant 7 (2016) indicated that "it is not about the CBE Code, it is part of the competition, banks will be outdated, if they do not disclose CSR". Instead, there was a recognition, among state banks in particular, of a need for a proactive strategy of maintaining/gaining moral legitimacy by espousing altruistic ideals and acknowledging these emerging challenges rather than merely reflecting instrumental and narrowly defined demands. One interviewee stated, "Of course, it tells people that we are here to help you, not to exploit you. Especially if we address poor people's needs such as health problems including cancer treatment" (Participant 10, 2013). Participant 5 said, "We work with the society, outreach locations that no one reaches and only then can they trust us" (2013). In this way, the organisational intentions appear to shift towards an understanding of legitimacy as one that reflects a relationship with an audience, rather than merely being a possession of the organisation (Suchman, 1995, p. 594). In this regard, the need for a more honest form of communication and accountability is seen to be central to the pursuance of moral legitimacy and this is reflected in one interviewee agreeing that "CSR disclosures are important and needed on banks' websites and generally in the media as it strengthens the relationship with stakeholders and enhances public confidence" (Participant 4, 2016). Lastly, one informant concluded that the recent "nationalism" discourse played an important part in the banks' agenda towards social responsibility and reporting, stating that "this is our country and we must help in building it, as we simply live in it and will reap the benefits, so when banks engage in CSR activities and report it, a wave will be created and other banks will try to match this up to be legitimate" (Participant 1, 2016). Therefore, there is an appreciation that CSR reporting has to be more encompassing and in line with the political CSR approach to ensure that any moral claims towards addressing Egypt's social and economic challenges cannot be undercut "by even an appearance of cynicism" (Suchman, 1995, p. 579).

Second, given the diversity of moral legitimacy strategies as highlighted by Suchman (1995), our interviewee evidence allowed to examine more closely particular aspects that managers are keener to emphasise from their political CSR activities. As a recognition of the need to shift from a pragmatic to moral legitimacy, one informant commented on the need to "tell society that we do care for them. Instead of spending 20 million Egyptian Pounds (EGP) on an advertisement on the TV, I can give this money to a hospital, and then report it on the website. This will lead to a huge impact" (Participant 5, 2016). There was also an acknowledgement that CSR reporting could hold banks to account regarding their impact on the society. One excellent example was highlighted by participants 9 and 3 who referred to the case of "Agrium," a Canadian fertiliser producer, which secured a 1-billion-dollar loan from the EBS [10] (CBC News, 2008) to finance a new nitrogen production plant in the city of Damietta on the Egyptian Mediterranean coast. This project was fiercely protested against by locals in Damietta and rejected by the Egyptian parliament (El-Kashef and El-Shazly, 2008), who cited environmental and health risks, eventually leading to suspending the project at the time. Participant 9 indicated that "for a consortium of banks to agree to such an environmentally controversial project was a lesson that banks must not only take environmental degradation risk more seriously, but also engage with stakeholders more effectively" (2016), stressing the importance of CSR reporting as part of an engagement with stakeholders. Furthermore, and taking into account the government's calls for more involvement in public development projects, some banks became involved in high impact CSR interventions. For example, the Bashaier El Khier project addressed the development of a very deprived area in the Egyptian city of Alexandria and was fully financed by a group of investors and banks (Farouk, 2016). The first phase [11] of this project included 285 buildings, totalling 6,192 housing units. In this regard, CSR engagement and reporting improved and one interviewee indicated that "If there is any bank who is willing to help, the government will like them... this makes everyone's life easier" (Participant 4, 2016). Another interviewee indicated that "CSR should address different segments of stakeholders and can include 
AAAJ 34,5

1070

scholarships, entrepreneurs and financial inclusion of marginalised social groups" (Participant 10, 2013). This very well explains a gradual shift of banks' focus from a "perception that CSR is philanthropy" (Participant 7, 2013) to a more mature view aligned with a political CSR approach.

As such, in considering the examples put forward by the interviewees, we contend that managers revealed a strong predilection for a consequential form of moral legitimacy whereby the emphasis of the CSR reporting is on providing concrete evidence of socially accepted outcomes (e.g. development projects; environmental risk management) and demonstrating the impact (consequences) of their political CSR activities. In the context of gaining moral legitimacy post-2011 revolution, managers were keen to highlight the consequences of their new projects as a way to "disentangle new activities from certain preexisting regimes, in which the [past] activities would seem marginal, ancillary or illegitimate" (Suchman, 1995, p. 586). In this way as well, such attempts at achieving consequential legitimacy can also help validate the procedures, structures and personnel being implemented in the different banks, and according to Suchman (1995, p. 580), consequential claims may also serve as signals of disposition in high-ambiguity settings, i.e. such as the one faced by banks after the revolution. Prior evidence supporting consequential legitimacy motivations in CSR reporting is quite limited and notably, one prior study (Soobaroyen and Ntim, 2013) conjectured that companies may be shifting their health-related disclosures (towards providing more information on the outcomes of CSR activities) in an attempt to enhance their moral legitimacy and as a result of increased societal concerns about a health crisis. In our case, and based on the interviews and cases flagged by our informants, we can observe how managers specifically conceive of the pursuit of moral legitimacy by emphasising the "consequential" features and outcomes of their CSR activities.

Thirdly, and notwithstanding our observations on consequential legitimacy, we also observe emerging interest among some managers and companies in seeking to professionalise CSR interventions. In particular, some local private banks have set up charitable foundations operating as entities separate from the parent bank with an express commitment to the country's new agenda for development, especially in the case of local banks such as bank Misr (who established the Banque Misr Foundation for Community Development) and the CIB Foundation. This was also noted in the case of the "We owe it to Egypt" foundation established by the Arab African bank (a joint venture bank between the Egyptian central bank and Kuwait Investment Authority, each party owning $49.37 \%$ ). Interviews with relevant informants revealed an interest with foundations to position and strengthen their CSR structure so that they are able to address societal challenges and communicate their social engagement in a more effective way. For example, one interviewee indicated that "in the past CSR was sort of business excellence but [now] developed to really paying back to the society... [their] vision focused on many aspects including health, education, youth internships and banking product development competitions available to university students, entrepreneurs' funding, environment; [bank name omitted] started measuring their CO2 footprint with a view of investing in sustainability" (Participant 7, 2013). Drawing upon Suchman's (1995) thoughts, we argue that this focus on charitable foundations is consistent with the pursuit of structural legitimacy since the setting up and reporting about charitable foundations enables the organisation to be seen as valuable and worthy of support since its structural characteristics position such organisations in a morally favoured taxonomic category. The reporting about charitable foundations reflects the message that an organisation is acting on collectively valued purposes in a proper and adequate manner (Suchman, 1995) and is able to engage more substantively with the relevant audience and broader political CSR priorities. 


\section{Conclusion, contributions, limitations and further work}

\subsection{Key findings}

Our research questions focused on the potentially evolving motivations underlying CSR reporting in developing countries. Although we acknowledge the insights from the literature on CSR reporting, which favour organisational legitimacy-led motivations in developing countries, we sought to extend the conceptual discussion to consider the rise (even if on a limited basis) of a normative thinking in businesses towards greater and substantive societal engagement in these contexts. In particular, we draw on Scherer and Palazzo's (2011) and Scherer et al. 's (2016) thoughts on political CSR (vs. instrumental CSR) and argue that the pursuit of specific types of organisational legitimacy (as set out by Suchman, 1995) leads to an alignment towards new societal expectations arising from a changing institutional environment (e.g. often as a result of crises, political upheavals or emergencies), which are reflected in particular themes/types of CSR disclosures.

The Egyptian context, post-2011 revolution, offered a useful context for considering our research questions, with an emphasis on the case of the banking sector. We first carry out a content analysis of the CSR disclosure themes (web and annual report) of Egyptian banks published in 2013 and 2016, by classifying their disclosures as instrumental/ pragmatic or political/moral and draw upon Scott's (2014) neo-institutional theory to analyse the broader societal pressures at play. Furthermore, mindful of the challenges in teasing out the existence of competing (or complementary) legitimacy motivations for CSR reporting from the analysis of CSR disclosures, we followed up with semi-structured interviews with bank managers, CSR managers, CSR academics/consultants and government officials.

First, our analysis of the Egyptian context settings identifies the implications of the 2011 revolution for companies and specifically for the banking sector. Amidst the "common" regulatory pressures (new code of governance requiring CSR disclosure and the dissemination of CSR practices from foreign/pioneer banks) that have, to an extent, spurred an instrumental/strategic reaction by banks, we also find a stronger affiliation to the need for a deeper and more substantive change towards helping the country address long-lasting development challenges (poverty, deficits in education and health). The State's new agenda also reflects this developmental focus and calls for all Egyptians and companies to contribute directly to development outcomes. These forces provide authoritative guidelines for social behaviour (Scott, 2005) and value systems relating to what is expected of companies in Egypt and which is in line with the political CSR approach. Consequently, from the above, we note that a higher proportion of banks in Egypt have started to privilege disclosures in relation to a set of political CSR themes (e.g. supporting public services, environment, the role of charitable foundations) that are aimed at achieving moral legitimacy, although there are still CSR disclosures relating to the banks' most immediate audiences (employees, regulators and customers) aimed at pursuing pragmatic legitimacy. This re-alignment is more applicable to the case of state-owned banks compared to local private or foreign banks.

Second, our interview data highlights the limited nature and "reach" of the regulatory changes (e.g. code of governance, $\mathrm{CBE}$ expectations) and the embedding by many managers of the political CSR approach in pursuing moral legitimacy. Crucially, the insights emphasise how an organisational concern with achieving consequential legitimacy (and to a lesser extent structural legitimacy) underpins the CSR changes and the concurrent changes in CSR reporting. Hence, while the content analysis reveals the change in CSR disclosure themes post 2011 revolution consistent with the pursuit of moral legitimacy (rather than just pragmatic legitimacy), the interview data complements this insight by highlighting the managerial preference for maintaining or gaining consequential legitimacy and structural legitimacy, together with a lesser emphasis on exchange legitimacy.

\section{disclosures in developing countries}

1071 
AAAJ

34,5

1072

\subsection{Contributions and implications}

The study makes several contributions to the CSR reporting literature. First, it highlights the relevance of Scherer and Palazzo's (2011) political CSR approach in developing countries. While there has been previous work in these contexts on the emergence of a normative approach to CSR in the context of institutional voids (Amaeshi et al., 2016; Sorour et al., 2020), there has been little elaboration of its implications for accountability and CSR reporting. This takes a particular resonance in view of the many political, economic and/or social upheavals in developing countries, often leading to a substantial re-examination of the role of business and the private sector. Second, CSR reporting in some developing countries has typically been seen as peripheral/absent (Jamali and Karam, 2016; Sorour et al., 2020; Ali et al., 2017) or would be seen as a symbolic impression management exercise that is primarily concerned with placating stakeholders and/or protecting a shareholder-focused agenda (Belal and Roberts, 2010; Islam and Deegan, 2008; Islam and Kokubu, 2018; Soobaroyen and Mahadeo, 2016; Lauwo et al., 2019). However, and while Egypt also faced regulatory and normative pressures (e.g. corporate governance code; dissemination of CSR reporting practices), the shift in CSR disclosures was mainly driven by moral legitimacy, which itself arose from an organisational imperative to align more deeply to the new societal expectations. We, therefore, suggest that researchers need to be attuned to the possibility of a blend of normative and instrumental motivations, particularly in the context of the development of CSR functions within organisations.

Third, we draw on Suchman's (1995) conceptualisation of exchange, consequential and structural legitimacy to frame the interviewees' insights into the reasons for banks to alter their CSR and CSR reporting practices. While there have been prior empirical analyses involving Suchman's dynamics of legitimacy to interpret patterns or trends in CSR disclosures (e.g. Soobaroyen and Ntim, 2013; Vithana et al., 2019), there is relatively little work on appreciating the organisational/managerial rationales on the basis of primary data. Finally, and while acknowledging recent CSR reporting studies in the Egyptian context (Darrag and Crowther, 2017; El-Bassiouny and Letmathe, 2019), our empirical findings report on new insights borne out of the recent sociopolitical changes and the relevance of other non-instrumental motivations in explaining the emergence/prevalence of CSR reporting practices.

\subsection{Limitations and further work}

We acknowledge the following challenges. First, while our approach has sought to establish the link between empirical data and Scherer and Palazzo's (2011) model of political CSR, it has been difficult to cover all aspects and practices undergone by companies. It would be useful to uncover other instances and characteristics of political CSR and its reporting in developing countries. Second, some of our work, such as the construction of a disclosure checklist and coding of the disclosures, does imply some subjectivity, which, inter alia, we sought to dampen by reviewing the coding by different raters. Thirdly, we agree that the views reported based on interviews may be somewhat biased due to our purposive sampling and given that it has been challenging to seek views from a wider cross-section of informants. For example, going forward, it may be useful to explore the views of managers or individuals that are directly involved in the design/preparation of CSR reports in understanding their micro-rationales for including/ excluding CSR information and engaging with the stakeholders who rely on such information.

\section{Notes}

1. The Egyptian banking sector is a major contributor to the local economy. For instance, bank assets represented 89.26\% of GDP in 2017 (The Global Economy, 2020). 
2. The authors included all relevant reports such as sustainability or corporate governance reports, i.e. any relevant reports available on the websites of banks, not just those revealed in annual reports. The justification for this is twofold. First, bearing in mind the infancy of CSR disclosure in Egypt and the gradual rise of Internet reporting, we sought to capture the complete range of CSR disclosure wherever it was disclosed. Second, Unerman (2000, p. 674) argued that "future studies focusing exclusively on annual reports might not produce particularly relevant results" (see also Zéghal and Ahmed, 1990).

3. A list of banks disclosing each year is included in Appendix 1.

CSR disclosures in developing countries

1073

4. One EGP equals 0.049 Sterling Pound

5. The Bashaier El Khier project addressed a particularly deprived area in the Egyptian city of Alexandria.

6. There are a number of other initiatives that facilitated the gradual introduction of the CSR concept as a business norm into the Egyptian business environment, as shown in Appendix 4.

7. Acquired by a Moroccan multinational commercial bank in 2017.

8. Established in 2010 as a non-profit organisation dedicated to enhancing health and nutritional services for underprivileged children in Egypt and registered under the Ministry of Social Solidarity as per the Ministry's Decree No. 588 of 2010, the CIB Foundation focuses on sustainable development initiatives that result in positive, long-term outcomes (CIB Foundation, 2020).

9. An additional table is available in Appendix 3, which provides the basis of the results reported in Table 4.

10. A consortium of nine banks (Banque Misr, National Bank of Egypt, Audi Bank, Credit Agricole, Greek National Bank, National Bank of Abu Dhabi, Commercial International Bank, National Bank of Development and United Bank).

11. There are also phases two and three, with a total of 558 residential buildings comprising 13,000 units.

\section{References}

Abdou, D.S. and Zaazou, Z. (2013), "The Egyptian revolution and post socio-economic impact”, Topics in Middle Eastern and African Economies, Vol. 15 No. 1, pp. 92-115.

Adelopo, I., Yekini, K. and Raimi, L. (2015), "Political corporate social responsibility and development", in Jamali, D., Karam, C. and Blowfield, M. (Eds), Development-Oriented Corporate Social Responsibility, Greenleaf Publishing, Sheffield, pp. 29-49, ISBN 9781783532452, available at: http://eprints.uwe.ac.uk/26635 (accessed 9 August 2020).

Aguinis, H. and Glavas, A. (2012), "What we know and don't know about corporate social responsibility: a review and research agenda", Journal of Management, Vol. 38 No. 4, pp. 932-968.

Ali, W., Frynas, J.G. and Mahmood, Z. (2017), "Determinants of corporate social responsibility (CSR) disclosure in developed and developing countries: a literature review", Corporate Social Responsibility and Environmental Management, Vol. 24 No. 4, pp. 273-294.

Alshorbagy, A.A. (2016), "CSR and the Arab spring revolutions: how is CSR not applied in Egypt", Wisconsin International Law Journal, Vol. 34 No. 1, pp. 1-34.

Amaeshi, K., Adegbite, E. and Rajwani, T. (2016), "Corporate social responsibility in challenging and non-enabling institutional contexts: do institutional voids matter?", Journal of Business Ethics, Vol. 134 No. 1, pp. 135-153.

Amran, A. and Haniffa, R. (2011), "Evidence in development of sustainability reporting: a case of a developing country", Business Strategy and the Environment, Vol. 20 No. 3, pp. 141-156.

Ashforth, B.E. and Gibbs, B.W. (1990), "The double-edge of organizational legitimation”, Organization Science, Vol. 1 No. 2, pp. 177-194. 
AAAJ 34,5
Athanasopoulou, A. and Selsky, J.W. (2015), "The social context of corporate social responsibility: enriching research with multiple perspectives and multiple levels", Business and Society, Vol. 54 No. 3, pp. 322-364.

Avina, J. (2013), "The evolution of corporate social responsibility (CSR) in the Arab spring”, Middle East Journal, Vol. 67 No. 1, pp. 77-92.

Barkemeyer, R., Preuss, L. and Lee, L. (2015), "On the effectiveness of private transnational governance regimes - evaluating corporate sustainability reporting according to the Global Reporting Initiative", Journal of World Business, Vol. 50 No. 2, pp. 312-325.

Banque Misr (2020), "Mashroai-Mashroak", available at: https://www.banquemisr.com/ar/fundingsmes/small-enterprises-projects (accessed 9 August 2020).

Bayoud, N.S., Kavanagh, M. and Slaughter, G. (2012), "An empirical study of the relationship between corporate social responsibility disclosure and organizational performance: evidence from Libya”, International Journal of Management and Marketing Research, Vol. 5 No. 3, pp. 69-82.

BBC (2016a), "السيسي يدعو الدصريين إلى التعاون لتحسين الوضع الاقتصادي", available at: http://www.bbc.com/ arabic/business/2016/08/160813_sisi_egypt_economy (accessed 9 August 2020).

BBC (2016b), “تويتر: "صبح على مصر بجنيه”, Sobh on Egypt with a pound (accessed 9 August 2020).

Beattie, V., McInnes, B. and Fearnley, S. (2004), "A methodology for analysing and evaluating narratives in annual reports: a comprehensive descriptive profile and metrics for disclosure quality attributes", Accounting Forum, Vol. 28 No. 3, pp. 205-236.

Belal, A.R. and Cooper, S. (2011), "The absence of corporate social responsibility reporting in Bangladesh", Critical Perspectives on Accounting, Vol. 22 No. 7, pp. 654-667.

Belal, A.R. and Roberts, R.W. (2010), "Stakeholders' perceptions of corporate social reporting in Bangladesh", Journal of Business Ethics, Vol. 97 No. 2, pp. 311-324.

Belal, A.R., Cooper, S.M. and Roberts, R.W. (2013), "Vulnerable and exploitable: the need for organisational accountability and transparency in emerging and less developed economies", Accounting Forum, Vol. 37 No. 2, pp. 81-91.

Blasco, M. and Zølner, M. (2010), "Corporate social responsibility in Mexico and France exploring the role of normative institutions", Business and Society, Vol. 49 No. 2, pp. 216-251.

Boyatzis, R.E. (1998), Transforming Qualitative Information, Thematic Analysis and Code Development, Sage Publications, Thousand Oaks, California, CA.

Bradly, A. and Nathan, G. (2019), "Institutional CSR: provision of public goods in developing economies”, Social Responsibility Journal, Vol. 15 No. 7, pp. 874-887.

Brammer, S., Jackson, G. and Matten, D. (2012), "Corporate social responsibility and institutional theory: new perspectives on private governance", Socio-Economic Review, Vol. 10 No. 1, pp. 3-28.

Bryman, A. and Bell, E. (2015), Business Research Methods, Oxford University Press, Oxford.

CBC News (2008), "Egypt cancels Agrium fertilizer plant", available at: http:/www.cbc.ca/news/ business/egypt-cancels-agrium-fertilizer-plant-1.695165 (accessed 9 August 2020).

CBE (2011), "Instructions on banks' governance", available at: http://www.cbe.org.eg/en/ BankingSupervision/Pages/ReformPhase1.aspx (accessed 9 August 2020).

Chekir, H. and Diwan, I. (2014), "Crony capitalism in Egypt", Journal of Globalization and Development, Vol. 5 No. 2, pp. 177-211.

Chelli, M., Durocher, S. and Fortin, A. (2019), "Substantive and symbolic strategies sustaining the environmentally friendly ideology: a media-sensitive analysis of the discourse of a leading French utility", Accounting, Auditing and Accountability Journal, Vol. 32 No. 4, pp. 1013-1042.

Cho, C.H. and Patten, D.M. (2007), "The role of environmental disclosures as tools of legitimacy: a research note", Accounting, Organizations and Society, Vol. 32 No. 7, pp. 639-647. 
Cho, C.H., Michelon, G., Patten, D.M. and Roberts, R.W. (2015), "CSR disclosure: the more things change...?”, Accounting, Auditing and Accountability Journal, Vol. 28 No. 1, pp. 14-35.

CIA (2015), "The world factbook Egypt”, available at: https://www.cia.gov/library/publications/theworld-factbook/geos/eg.html (accessed 9 August 2020).

CIB (2020), "CIBFoundation", available at: https://www.cibeg.com/English/CIBCommunity/Pages/ CIBFoundation.aspx y (accessed 9 August 2020).

Collins, C.S. and Stockton, C.M. (2018), "The central role of theory in qualitative research", International Journal of Qualitative Methods, Vol. 17 No. 1, pp. 1-10.

Darrag, M. and Crowther, D. (2017), "Reflections on CSR: the case of Egypt", Society and Business Review, Vol. 12 No. 1, pp. 94-116.

Darrag, M. and E-Bassiouny, N. (2013), "An introspect into the Islamic roots of CSR in the Middle East: the case of Savola Group in Egypt”, Social Responsibility Journal, Vol. 9 No. 3, pp. 362-378.

De Villiers, C. and Van Staden, C.J. (2006), "Can less environmental disclosure have a legitimising effect?, Evidence from Africa", Accounting, Organizations and Society, Vol. 31 No. 8, pp. 763-781.

Deegan, C. and Unerman, J. (2006), Financial Accounting Theory: European Edition, McGraw-Hill, Maidenhead.

ECRC (2017a), Egyptian Corporate Responsibility Centre, available at: http://www.ecrc.org.eg/ WhoWeAre.aspx (accessed 2 July 2017).

ECRC (2017b), Egyptian Corporate Responsibility Centre, available at: http://www.ecrc.org.eg/backend/ uploads/publications/docs/ECRC\%20Brochures.pdf (accessed 2 July 2017).

ECCG (Egyptian Code of Corporate Governance) (2005), Egypt Code of Corporate Governance: Guidelines and Standards, Egyptian Institute of Directors.

ECCG (Egyptian Code of Corporate Governance) (2011), Egypt Code of Corporate Governance: Guidelines and Standards, Egyptian Institute of Directors.

Egbon, O., Idemudia, U. and Amaeshi, K. (2018), "Shell Nigeria's global memorandum of understanding and corporate-community accountability relations", Accounting, Auditing and Accountability Journal, Vol. 31 No. 1, pp. 51-74.

Egypt independent (2016), "Long live Egypt fund", available at: www.dailynewsegypt.com/tag/longlive-egypt-fund/ (accessed 9 August 2020).

El-Bassiouny, D. and Letmathe, P. (2019), "Political instability and corporate social responsibility: the case of Egypt”, Social Responsibility Journal, Vol. 16 No. 5, pp. 745-767.

El-Kashef, N. and EI-Shazly, E. (2008), Massive Protests in Damietta to Demand Moving the Factory 'Agrium' and the Governorate Councils Freeze Activities until a Decision to Move Is Issued, AlMasry Al-Youm, Cairo, in Arabic.

El-Kayaly, D. (2014), “Corporate social responsibility supporting SMEs: lessons learned from Egypt", Maastricht School of Management Working Paper, available at: http://web2.msm.nl/RePEcl msm/wpaper/MSM-WP2014-25.pdf (accessed 9 August 2020).

El-Said, H. (2009), "Overview of corporate governance in the EBS", Paper presented at Corporate Governance in the Banking Sector, the Safeguard, Marriott Hotel, Cairo.

Elshabasy, Y.N. (2018), "The impact of corporate characteristics on environmental information disclosure: an empirical study on the listed firms in Egypt", Journal of Business and Retail Management Research, Vol. 12 No. 2, pp. 232-241.

Fadel, M. (2011), "Public corruption and the Egyptian revolution of January 25: can emerging international anti-corruption norms assist Egypt recover misappropriated public funds?", Harvard International Law Journal, Vol. 52, pp. 1-9.

Farouk, M. (2016), “Al akaria journal", available at: http://www.aleqaria.com.eg/show-1550.html (accessed 9 August 2020).

\section{disclosures in developing countries}

1075 
AAAJ

34,5

Gallhofer, S., Haslam, J. and van der Walt, S. (2011), “Accountability and transparency in relation to human rights: a critical perspective reflecting upon accounting, corporate responsibility and ways forward in the context of globalisation”, Critical Perspectives on Accounting, Vol. 22 No. 8, pp. 765-780.

Global Reporting Initiative (2017), "GRI discussion paper corporate reporting on poverty", available at: https://www.globalreporting.org/resourcelibrary/GRI-OnPovertyPaper.pdf (accessed 9 August 2020).

Gray, R., Kouhy, R. and Lavers, S. (1995), "Corporate social and environmental reporting", Accounting, Auditing and Accountability Journal, Vol. 8 No. 2, pp. 47-77.

Hooks, J. and Van-Staden, C.J. (2011), "Evaluating environmental disclosures: the relationship between quality and extent measures", The British Accounting Review, Vol. 43 No. 3, pp. 200-213.

Hopper, T., Lassou, P. and Soobaroyen, T. (2017), "Globalisation, accounting and developing countries”, Critical Perspectives on Accounting, Vol. 43, pp. 125-148.

Hrasky, S. (2012), "Carbon footprints and legitimation strategies: symbolism or action?", Accounting, Auditing and Accountability Journal, Vol. 25 No. 1, pp. 174-198.

Hsieh, H.F. and Shannon, S.E. (2005), "Three approaches to qualitative content analysis", Qualitative Health Research, Vol. 15 No. 9, pp. 1277-1288.

Idemudia, U. (2011), "Corporate social responsibility and developing countries: moving the critical CSR research agenda in Africa forward”, Progress in Development Studies, Vol. 11 No. 1, pp. 1-18.

Islam, M. and Deegan, C. (2008), "Motivations for an organisation within a developing country to report social responsibility information: evidence from Bangladesh”, Accounting, Auditing and Accountability Journal, Vol. 21 No. 6, pp. 850-874.

Islam, M.T. and Kokubu, K. (2018), "Corporate social reporting and legitimacy in banking: a longitudinal study in the developing country", Social Responsibility Journal, Vol. 14 No. 1, pp. 159-179.

Jain, T., Aguilera, R. and Jamali, D. (2016), "Corporate stakeholder orientation in an emerging country context: a longitudinal cross industry analysis", Journal of Business Ethics, Vol. 143, pp. 1-19.

Jamali, D. and Karam, C. (2016), "CSR in developed versus developing countries: a comparative glimpse", in Research Handbook on Corporate Social Responsibility in Context, Edward Elgar Publishing.

Jamali, D. and Karam, C. (2018), "Corporate social responsibility in developing countries as an emerging field of study”, International Journal of Management Reviews, Vol. 20 No. 1, pp. 32-61.

Jamali, D. and Neville, B. (2011), "Convergence versus divergence of CSR in developing countries: an embedded multi-layered institutional lens”, Journal of Business Ethics, Vol. 102 No. 4, pp. 599-621.

Jamali, D.R., El Dirani, A.M. and Harwood, I.A. (2015), "Exploring human resource management roles in corporate social responsibility: the CSR-HRM co-creation model", Business Ethics: A European Review, Vol. 24 No. 2, pp. 125-143.

Jamali, D., Lund-Thomsen, P. and Khara, N. (2017), "CSR institutionalized myths in developing countries: an imminent threat of selective decoupling”, Business and Society, Vol. 56 No. 3, pp. 454-486.

Kamla, R. (2007), "Critically appreciating social accounting and reporting in the Arab Middle East: a postcolonial perspective", Advances in International Accounting, Vol. 20, pp. 105-177.

Kenawy, E.M. and Abd-el Ghany, M.F. (2012), "The economic importance of venture capital as new funding alternative with reference to the Egyptian experience", Journal of Basic and Applied Scientific Research, Vol. 2 No. 4, pp. 3598-3606.

Khan, M., Lockhart, J. and Bathurst, R. (2020), "A multi-level institutional perspective of corporate social responsibility reporting: a mixed-method study", Journal of Cleaner Production, Vol. 265, pp. 1-14. 
Kilic, M. (2016), "Online corporate social responsibility (CSR) disclosure in the banking industry: evidence from Turkey", International Journal of Bank Marketing, Vol. 34 No. 4, pp. 550-569.

Kim, J., Bach, S. and Clelland, I. (2007), "Symbolic or behavioural management? Corporate reputation in high emission industries", Corporate Reputation Review, Vol. 10 No. 2, pp. 77-98.

Kühn, A.L., Stiglbauer, M. and Fifka, M.S. (2018), "Contents and determinants of corporate social responsibility website reporting in Sub-Saharan Africa: a seven-country study", Business and Society, Vol. 57 No. 3, pp. 437-480.

Landis, J.R. and Koch, G.G. (1977), "An application of hierarchical kappa-type statistics in the assessment of majority agreement among multiple observers", Biometrics, Vol. 33 No. 2, pp. 363-374.

Lauwo, S., Kyriacou, O. and Otusanya, O.J. (2019), "When sorry is not an option: CSR reporting and 'face work' in a stigmatised industry-A case study of Barrick (Acacia) gold mine in Tanzania", Critical Perspectives on Accounting, Vol. 71, pp. 1-23.

Lehman, G. and Kuruppu, S.C. (2017), "A framework for social and environmental accounting research", Accounting Forum, Vol. 41 No. 3, pp. 139-146.

Li, T. and Belal, A. (2018), "Authoritarian state, global expansion and corporate social responsibility reporting: the narrative of a Chinese state-owned enterprise", Accounting Forum, Vol. 42 No. 2, pp. 199-217, Taylor and Francis.

Lincoln, S.Y. and Guba, E.G. (1985), Naturalistic Inquiry, Sage, Thousand Oaks, CA.

Llewellyn, J. (2007), "Government, business, and the self in the United States", in May, S.K., Cheney, G. and Roper, J. (Eds), The Debate over Corporate Social Responsibility, Oxford University Press, pp. 177-189.

Mahadeo, J.D., Oogarah-Hanuman, V. and Soobaroyen, T. (2011), "Changes in social and environmental reporting practices in an emerging economy (2004-2007): exploring the relevance of stakeholder and legitimacy theories", Accounting Forum, Vol. 35 No. 3, pp. 158-175.

Marquis, C., Toffel, M.W. and Zhou, Y. (2016), "Scrutiny, norms, and selective disclosure: a global study of greenwashing", Organization Science, Vol. 27 No. 2, pp. 483-504.

Marston, C.L. and Shrives, P.J. (1991), "The use of disclosure indices in accounting research: a review article", The British Accounting Review, Vol. 23 No. 3, pp. 195-210.

McWilliams, A. and Siegel, D. (2000), "Corporate social responsibility and financial performance: correlation or misspecification?”, Strategic Management Journal, Vol. 21 No. 5, pp. 603-609.

Milne, M.J. and Adler, R.W. (1999), "Exploring the reliability of social and environmental disclosures content analysis", Accounting, Auditing and Accountability Journal, Vol. 12 No. 2, pp. 237-256.

Momin, M.A. and Parker, L.D. (2013), "Motivations for corporate social responsibility reporting by MNC subsidiaries in an emerging country: the case of Bangladesh", The British Accounting Review, Vol. 45 No. 3, pp. 215-228.

Muthuri, J.N. and Gilbert, V. (2011), "An institutional analysis of corporate social responsibility in Kenya”, Journal of Business Ethics, Vol. 98 No. 3, pp. 467-483.

Muthuthi, C. (2014), “African economic outlook 2014”, available at: http://www.un.org/en/africa/osaa/ pdf/pubs/2014afrecooutlook-afdb.pdf (accessed 9 August 2020).

O'Dwyer, B. (2004), “Qualitative data analysis: illuminating a process for transforming a 'messy' but 'attractive "nuisance", The Real Life Guide to Accounting Research, Elsevier, pp. 391-407.

Osman, M.N. (2019), "Social reporting of Egyptian islamic banks: insights from the post-revolution era”, Financing Sustainable Development, Palgrave Macmillan, Cham, pp. 341-369.

Sandhu, S., Smallman, C., Ozanne, L.K. and Cullen, R. (2012), "Corporate environmental responsiveness in India: lessons from a developing country", Journal of Cleaner Production, Vol. 35, pp. 203-213.

Sannassee, R.V., Soobaroyen, T. and Pariag-Maraye, N. (2017), "The accountability and management control of CSR Foundations (CRSFs) in Mauritius", CIMA Research Executive Summary, Vol. 13 No. 4, pp. 1-12.

\section{disclosures in developing countries}


AAAJ 34,5

Scherer, A.G. (2018), "Theory assessment and agenda setting in political CSR: a critical theory perspective", International Journal of Management Reviews, Vol. 20 No. 2, pp. 387-410.

Scherer, A.G. and Palazzo, G. (2011), "The new political role of business in a globalized world: a review of a new perspective on CSR and its implications for the firm, governance, and democracy", Journal of Management Studies, Vol. 48 No. 4, pp. 899-931.

Scherer, A.G., Rasche, A., Palazzo, G. and Spicer, A. (2016), "Managing for political corporate social responsibility: new challenges and directions for PCSR 2.0", Journal of Management Studies, Vol. 53 No. 3, pp. 273-298.

Scholtens, B. (2009), "Corporate social responsibility in the international banking industry", Journal of Business Ethics, Vol. 86 No. 2, pp. 159-175.

Schreier, M. (2012), Qualitative Content Analysis in Practice, Sage Publications, London.

Scott, W.R. (2005), "Institutional theory: contributing to a theoretical research program", Great Minds in Management: The Process of Theory Development, Vol. 37 No. 2005, pp. 460-484.

Scott, W.R. (2014), Institutions and Organizations Ideas, Interests, and Identities, Sage Publications, Thousand Oaks, California.

Sherif, D.H. and Sharara, N. (2016), Expanding Horizons in Development: The Rising Role of the Private Sector, United Nations Development Programme (UNDP), and the Industrial Modernization Center (IMC), Cairo.

Soobaroyen, T. and Mahadeo, J.D. (2016), "Community disclosures in a developing country: insights from a neo-pluralist perspective", Accounting, Auditing and Accountability Journal, Vol. 29 No. 3, pp. 452-482.

Soobaroyen, T. and Ntim, C.G. (2013), "Social and environmental accounting as symbolic and substantive means of legitimation: the case of HIV/AIDS reporting in South Africa", Accounting Forum, Vol. 37 No. 2, pp. 92-109.

Sorour, M.K., Boadu, M. and Soobaroyen, T. (2020), "The role of corporate social responsibility in organisational identity communication, co-creation and orientation", Journal of Business Ethics, pp. 1-20, doi: 10.1007/s10551-020-04481-w.

Stemler, S. (2001), "An overview of content analysis", Practical Assessment, Research and Evaluation, Vol. 7 No. 17, pp. 137-146.

Suchman, M.C. (1995), "Managing legitimacy: strategic and institutional approaches", Academy of Management Review, Vol. 20 No. 3, pp. 571-610.

Suddaby, R., Bitektine, A. and Haack, P. (2017), "Legitimacy", Academy of Management Annals, Vol. 11 No. 1, pp. 451-478.

Teti, A. and Gervasio, G. (2011), "The Unbearable lightness of authoritarianism: lessons from the Arab uprisings", Mediterranean Politics, Vol. 16 No. 2, pp. 321-327.

The Global Economy (2020), available at: www.theglobaleconomy.com/Egypt/bank_assets_GDP/.

Thompson, P. and Zakaria, Z. (2004), "Corporate social responsibility reporting in Malaysia”, Journal of Corporate Citizenship, Vol. 13 No. 2004, pp. 125-136.

Tremblay, M.S. and Gendron, Y. (2011), "Governance prescriptions under trial: on the interplay between the logics of resistance and compliance in audit committees", Critical Perspectives on Accounting, Vol. 22 No. 3, pp. 259-272.

Uddin, S., Siddiqui, J. and Islam, M.A. (2018), "Corporate social responsibility disclosures, traditionalism and politics: a story from a traditional setting", Journal of Business Ethics, Vol. 151 No. 2, pp. 409-428.

Unerman, J. (2000), "Methodological issues: reflections on quantification in corporate social reporting content analysis”, Accounting, Auditing and Accountability Journal, Vol. 13 No. 5, pp. 667-680.

UN Global Compact (2019), available at: https://www.unglobalcompact.org/ (accessed 9 August 2020). 
UNECA (2011), “Corporate Social responsibility initiatives", Minerals and Africa's Development the International Study Group Report on Africa's Mineral Regimes, Addis Ababa, pp. 81-89.

Vigneau, L., Humphreys, M. and Moon, J. (2015), "How do firms comply with international sustainability standards? Processes and consequences of adopting the global reporting initiative", Journal of Business Ethics, Vol. 131 No. 2, pp. 469-486.

disclosures in developing countries

Vithana, K., Soobaroyen, T. and Ntim, C.G. (2019), "Human resource disclosures in UK corporate annual reports: to what extent do these reflect organisational priorities towards labour?", Journal of Business Ethics, Vol. 12 No. 1, pp. 1-23.

Wanderley, L.S.O., Lucian, R., Farache, F. and De Sousa Filho, J.M. (2008), "CSR information disclosure on the web: a context-based approach analysing the influence of country of origin and industry sector", Journal of Business Ethics, Vol. 82 No. 2, pp. 369-378.

Wang, K.T. and Li, D. (2016), "Market reactions to the first-time disclosure of corporate social responsibility reports: evidence from China", Journal of Business Ethics, Vol. 138 No. 4, pp. 661-682.

Zéghal, D. and Ahmed, S.A. (1990), "Comparison of social responsibility information disclosure media used by Canadian firms", Accounting, Auditing and Accountability Journal, Vol. 3 No. 1, pp. 38-53.

Zhu, Q. and Zhang, Q. (2015), "Evaluating practices and drivers of corporate social responsibility: the Chinese context", Journal of Cleaner Production, Vol. 100 No. 1, pp. 315-324.

\section{Further reading}

DiMaggio, P.J. and Powell, W.W. (1983), "The Iron cage revisited: institutional isomorphism and collective rationality in organizational fields", American Sociological Review, Vol. 48 No. 2, pp. 147-160.

\section{Appendix}

The Appendix files are available online for this article.

\section{Corresponding author}

M. Karim Sorour can be contacted at: karim.sorour@northumbria.ac.uk

For instructions on how to order reprints of this article, please visit our website:

www.emeraldgrouppublishing.com/licensing/reprints.htm

Or contact us for further details: permissions@emeraldinsight.com 